\title{
Populism as Dog-Whistle Politics: Anti-Elite Discourse and Sentiments toward Minority Groups
}

\author{
Bart Bonikowski \\ New York University \\ bonikowski@nyu.edu
}

Yueran Zhang

University of California, Berkeley

yueranzhang@berkeley.edu

\begin{abstract}
Past research has devoted more attention to the consequences of populism for party politics and governance than to the effects of populist claims on public attitudes - and particularly, to how populism interacts with nationalism to exacerbate exclusionary beliefs among the public. Using online survey experiments, we examine whether exposure to populism increases out-group antipathy among Democrats and Republicans. In Study 1, we randomly assign respondents to three conditions featuring vignettes based on political speeches: a morally neutral argument, a populist critique of political elites, and a morally framed anti-immigration appeal. The results demonstrate that the populist treatment generates lower feeling-thermometer ratings of minority groups than the control condition, but only among Republicans and Trump supporters. Study 2 uses a similar design to evaluate the link between left-wing economic populism and economic nationalism: the populist condition features a critique of economic elites, the nationalist condition blames China for the offshoring of U.S. jobs, and the outcome variable measures respondents' sentiments toward China. Economic nationalism generates increased chauvinism among conservative Democrats but economic populism does not. Together these findings suggest that the cross-domain effects of populism on nationalism observed in Study 1 are driven by the discursive bundling of anti-elite talk with ethno-nationalism on the right, which stands in contrast to the decoupling of economic populism and economic nationalism on the left. The former has effectively turned populism into a form of dog-whistle politics among Republicans.
\end{abstract}

Acknowledgments: We are grateful for feedback on past versions of the paper from Eva Anduiza, Alexander Agadjanian, Kirk Hawkins, Omar Lizardo, Peter Loewen, Jeff Manza, Kristina Bakkær Simonsen, Jason Seawright, Bram Spruyt, Maya Tudor, Kim Williams, Cara Wong, Andrej Zaslove, and audience members at UCLA, CASBS, and Politicologetmaal. The research was supported by the Center for Advanced Study in the Behavioral Sciences at Stanford University and the Dean's Competitive Fund for Promising Scholarship at Harvard University. 
Research on the consequences of populism has been primarily focused on policy (Minkenberg 2001; Pappas, Mednez, and Herrick 2009; Zaslove 2004), governance (Akkerman and de Lange 2012; Kaltwasser and Taggart 2015; Pappas 2013), voting (Spiering and Zaslove 2017; Van Hauwaert and Van Kessel 2018), and the structure of party politics (Art 2007; de Lange 2012; Fallend and Heinisch 2015). Less attention has been devoted to the effects of populist discourse on attitudes, particularly among those who actively support populist parties and politicians. Given that populism is based on moral critiques of elites and the glorification of "the people," it is likely to affect trust in democratic institutions and the perceived legitimacy of elected officials, civil servants, and experts. But populist discourse may also have consequences less directly related to its anti-elite orientation. Among radical-right candidates (but rarely their radical-left counterparts), anti-elite rhetoric has been frequently accompanied by ethno-nationalist hostility toward immigrants and minorities (Ivarsflaten 2008; Mudde 2007; Rydgren 2008; Vahudova 2020), which raises the possibility of cross-domain effects, whereby anti-elite talk alone may prime greater antipathy toward minorities.

Our study examines these effects among respondents in the United States. Does populism targeting political elites effectively function as a form of ethnoracial dog-whistle politics? ${ }^{1}$ And if so, is this effect present among audiences across the political spectrum or primarily those on the right, where ethno-nationalist populism has been most prevalent? Finally, does populism focused on economic elites, most common on the political left, have comparable cross-domain effects vis-à-vis chauvinism, that is, negative sentiments toward countries blamed for the

\footnotetext{
1 "Dog-whistle politics" refers to the use of ostensibly innocuous discursive cues that prime more insidious outgroup hostilities, particularly among those who share the ideological predilections of the speaker. The metaphor refers to high-pitched dog-training whistles that use frequencies inaudible to humans.
} 
offshoring of U.S. manufacturing jobs, unfair trade practices, and other negative economic outcomes?

These questions are important for both substantive and theoretical reasons. Right-wing populist parties have drawn support from segments of the population strongly opposed to immigration and hostile toward minorities (Ivarsflaten 2008; Rydgren 2008). But these sentiments are not new - they have been part of the cultural landscape of most Western countries for decades (Smith 1997; Bonikowski and DiMaggio 2016) and tend to be stable over time (Kustov, Laaker, and Reller 2021). It is the ability of the radical right to effectively activate these pre-existing beliefs that has fueled its recent successes (Dennison and Geddes 2019; Hopkins 2021). What is less clear is whether this newfound resonance is solely a result of explicitly ethno-nationalist discourse or if it is also reinforced by populist anti-elite talk. If the latter were true, this would suggest that populism itself can stand in for the host ideologies to which it is attached. We posit that such cross-domain effects may be the result of the frequent discursive bundling of right-wing populism with ethno-nationalist claims.

Using a preregistered survey experiment design, our paper seeks to determine whether exposure to populist political discourse increases respondents' out-group antipathies. In Study 1, we presented respondents with one of three vignettes, featuring morally neutral claims, anti-elite discourse targeting politicians, and anti-immigration discourse, and then asked them to report their sentiments toward a range of minority groups. The results demonstrate that populist talk alone can activate hostility toward minority groups — as evidenced by lower feeling thermometer scores in the populist condition compared to the control condition—but only among Republican respondents and Trump supporters, constituencies most directly exposed to (and presumably favorable toward) the bundling of populism and ethno-nationalism in political discourse. 
To further test our intuitions about the effects of discursive bundling, we carried out a second experiment, which followed a similar design, but examined whether economic populism, commonly found on the political left, triggers chauvinism. ${ }^{2}$ We focus on conservative Democrats who, as we show, are likely to hold both sets of attitudes but who have not been exposed to political discourse that bundles together the corresponding frames. Although exposure to economic nationalism did increase hostility toward China among this group, economic populism did not - that is, we found no evidence of cross-domain effects. ${ }^{3}$

Taken together, the two studies document the capacity of seemingly innocuous anti-elite talk to heighten out-group hostility in other domains of social life and to mobilize political support among ethno-nationalist segments of national polities. Moreover, they suggest that discursive bundling is the most likely mechanism accounting for these cross-domain effects on the right and their absence on the left.

\section{Populism}

Populist politics have been a topic of growing attention in Europe and the United States, as radical parties and candidates have mobilized sizeable segments of national electorates using anti-elite appeals. The academic literature on this topic has been concerned with defining the phenomenon (e.g., Deegan-Krause and Haughton 2009), understanding the sources of support-

\footnotetext{
${ }^{2}$ In our usage, "economic nationalism" refers to political claims that frame international economic competition in zero-sum terms, privilege domestic production, and encourage trade protectionism. By "chauvinism," we mean perceptions of national superiority that are often accompanied by the moral denigration of other countries. The economic nationalism treatment condition in Study 2 combines these two frames, so we refer to it as "chauvinistic economic nationalism" or simply "economic nationalism" Finally, low scores on the China feeling thermometer that serves as the dependent variable in Study 2 can be interpreted as a country-specific measure of chauvinism, but not necessarily of economic nationalism, since the item is not specific to the economic domain.

${ }^{3}$ In direct contrast to Study 1, economic populism also fails to generate greater antipathy toward minority and immigrant groups. We do not foreground this result, however, because it represents a less plausible test of the posited mechanism, given that ethno-nationalism is not a salient feature of contemporary radical-left political discourse in the United States.
} 
both attitudinal and structural—for populist parties (e.g., Berezin 2009; Ivarsflaten 2008), and examining the consequences of the rise of populism for policy and party politics (e.g., de Lange 2012). In so doing, studies often conflate populism with the political ideologies to which it is attached, so that in effect, right-wing populism, ethno-nationalism, and, in some cases, welfare chauvinism or Euroskepticism are treated as a single ideological complex used to classify parties. More recently, however, scholars have called for the analytical separation of populism from associated political ideologies in order to study predictors and consequences specific to populism itself (Aslanidis 2016; Bonikowski 2017; Moffit and Tormey 2013; Rooduijn and Akkerman 2015). Our paper builds on this approach by examining whether exposure to populist discourse has implications for influencing or triggering specific social attitudes at the micro level.

How do we conceptualize populism? Whereas some scholars have framed populism as a thin-centered ideology or political practice (Mudde 2007; Jansen 2011), we rely on a discursive definition of the phenomenon (Bonikowski and Gidron 2016; Hawkins and Kalwasser 2017; Dai and Kustov 2022). Populism is a type of political claims-making predicated on a moral opposition between corrupt elites and the virtuous people, with the latter viewed as the only legitimate source of political power. Populist discourse seeks to mobilize support for political campaigns and policy initiatives by capitalizing on institutional distrust and anti-elite sentiments among politically disaffected segments of the population (Akkerman, Mudde, and Zaslove 2013; Rico, Guinjoan, and Anduiza 2017; Schulz et al. 2017; Spruyt, Keppens, and Droogenbroeck 2016).

The discursive approach to populism research is sensitive to context, because it assumes that the same political actor may use populism in one setting but not another. More importantly for our purposes, it also suggests that populism should be located not in the ideological 
commitments of parties, but rather in the content of political speech itself. It is at the point of contact between politicians and citizens that populism is most potent.

As past research has shown, populism can be found on both sides of the political spectrum. On the left, it tends to take an economic form, with the vilified elites consisting of business leaders and their political allies. On the right, populism frequently targets elected officials and civil servants, who are viewed as having forsaken the common good in favor of their own interests. At the same time, right-wing populism frequently lays blame for social and economic problems on ethnic, racial, and religious minorities and immigrants, the purported beneficiaries of disproportionately favorable treatment by out-of-touch political elites. This has led some scholars to conclude that right-wing populism tends to be exclusionary (Mudde and Kaltwasser 2013), while left-wing populism is more likely to be inclusive (Madrid 2008).

\section{Out-Group Antipathy}

The connection between right-wing populist discourse and ethnoracial exclusion is not limited to the messaging of parties and politicians - it extends to the beliefs of the parties' supporters as well. Studies have demonstrated that those susceptible to right-wing populist claims, both in the United States and Europe, tend to hold more negative attitudes toward immigrants and racial, ethnic, and religious minorities (Ivarsflaten 2008; Oliver and Rahn 2016; Rydgren 2008; Oesch 2008). ${ }^{4}$ It is plausible then that when supporters of right-wing populist candidates are exposed to populist claims in defense of "the people," they interpret such claims as code for "people like us"- that is, white and native born (in majority-white countries), and more often than not,

\footnotetext{
${ }^{4}$ This does not preclude the possibility that populism also exploits some voters' political disaffection, economic insecurity, and anxiety about cultural change without associating those grievances with out-group hostility.
} 
lacking college degrees and residing outside of major urban centers (Cramer 2016; Gidron and Hall 2017).

A possible way to conceptualize these exclusionary sentiments is with reference to specific out-group antipathies, perhaps brought together under the concepts of racism, xenophobia, or Islamophobia. The limitation of this approach, however, is that it does not provide a single theoretical framework that takes into account the extensive variation across countries in the specific out-groups targeted by radical-right politicians. ${ }^{5}$ What common denominator might account for the vilification of African Americans, Latinos, and Muslims (as well as, more recently, Asian Americans) in the United States, of North African Muslims in Western Europe, of Eastern European migrants in the pre-Brexit United Kingdom, or of Jews in Eastern Europe? One answer is that what these cases share is the political activation of an ethnonationalist collective identity that restricts legitimate national membership to those who hold the "right" ascriptive attributes, which often involve some combination of majority race or ethnicity, native birth, national ancestry, fluency in the country's dominant language, and adherence to its majority religion. It is this exclusionary in-group identity that leads to the denigration and scapegoating of a wide range of minority groups, in some cases immigrant and in others nativeborn (Kinder and Kam 2010).

The association between right-wing populism and ethno-nationalism raises two theoretical questions. First, why do these ideational phenomena frequently co-occur in political discourse and, if our intuitions are correct, in populist supporters' minds? Second, might

\footnotetext{
${ }^{5}$ Our broad conceptualization of ethnonationalism follows Loveman's (1999), Brubaker's (2002), and Wimmer's (2008) view of group boundaries as varied in content and salience across contexts and time. We acknowledge that there is some tension - to us, not irreconcilable - between this approach and work that privileges race as an analytical category distinct and superordinate to ethnic and religious symbolic boundaries (see, e.g., Bonilla-Silva 1997, 2006; Omi and Winant 2014).
} 
economic populism, typically found on the political left, generate out-group antipathies as well and if so, toward whom?

One way to think about the co-occurrence of populism and ethno-nationalism is in terms of elective affinity. Because populism is not a full-fledged ideology (Freeden 1996) but a discursive strategy for framing other political claims, it necessarily coexists with other ideological content. Moreover, its moral vilification of elites and glorification of the people requires discursive elaboration: populist leaders must articulate which elites are corrupt and who constitutes the people (Laclau 2005). Although references to the people are often vague in rightwing populist talk (e.g., using the first-person plural pronoun), they often implicitly signal who is not included in the category: immigrants and racial, ethnic, and religious minorities (Rooduijn and Pauwels 2011). The invocation of ethno-nationalist exclusion solves the rhetorical problem of defining the morally binary categories of populist claims.

The co-occurrence of populism and ethno-nationalism on the right, however, does not mean that these two phenomena are coterminous. Many parties—particularly on the left—engage in populism without invoking ethnoracial exclusion. How then does left-wing populism define "the people"? Both the vilified elites and "the people" are typically framed in economic termsfor instance, as workers, tax-payers, or the 99 percent. Because social and symbolic boundaries based on income, wealth, and class are highly resonant and many left-wing supporters hold social inclusive attitudes, left-wing populism is rarely explicitly exclusionary. But to the degree that we might expect left-wing populism to generate out-group antipathies, these are more likely to operate via chauvinism than ethno-nationalism, since Democrats tend to hold more positive views of domestic minorities than of countries perceived to have displaced American jobs and increased unemployment and economic precarity (Mirilovic and Kim 2017). We test the 
possibility of directly priming these protectionist and chauvinist attitudes in Study $2 .{ }^{6}$ Our expectation is that such attitudes may be activated by economic nationalism but not economic populism, because these two frames have not been directly bundled in the political discourse of recent progressive Democratic candidates, such as Bernie Sanders or Elizabeth Warren.

Returning to the socially exclusionary logic of right-wing populism, why is it that race and ethnicity rather than, for instance, wealth or education constitute the relevant criteria for defining "the people"? The short answer is that what primarily drives right-wing populism is status threat (Abascal 2015; Blumer 1958; Bobo 1999; Bobo and Hutchings 1996). Negative racial attitudes triggered by perceived threat to dominant groups' position in the racial status hierarchy have been empirically linked to greater commitment to conservative ideology and the Republican Party (Craig and Richeson 2014a), discrimination against ethnic minority and foreign-born welfare claimants (Ford 2016), racially biased definitions of academic merit (Samson 2013), and greater propensity to support the Tea Party (Willer, Feinberg, and Wetts 2016). They are also among the drivers of support for radical-right parties and candidates (McVeigh and Estep 2019; Reny et al. 2019; Sides, Tesler, and Vavreck 2018). Consistent with this literature, we are interested in respondents' antipathies toward a range of minority groups that may be seen as threatening to the dominant status of the native-born and/or white majority.

\section{Dog-Whistle Politics}

How should we theorize the cross-domain effects of populist discourse on nationalist attitudes?

Research in social and political psychology demonstrates that racial threat need not be

\footnotetext{
${ }^{6}$ We view antipathies toward domestic minorities and foreign countries as two distinct variants of ingroup-outgroup dynamics: Republicans tend to treat both domestic minorities and other countries as out-groups, whereas for Democrats, other countries - particularly those seen as economic, political, or military foes - are much more likely to be the targets of denigration than are domestic minorities. This is consistent with past research that has shown chauvinism - but not ethno-nationalism - to cut across partisan identification (Bonikowski and DiMaggio 2016).
} 
communicated explicitly in order to provoke out-group hostility (Messing, Jabon, and Plaut 2015; Mendelberg 2001; Wetts and Willer 2019; Willer, Feinberg, and Wetts 2016). Indeed, U.S. politics is rife with examples of coded language intended to mobilize (mostly, but not exclusively white) voters through subtle appeals to racial resentment, as evidenced by Nixon's Southern Strategy and its imagery of the "silent majority," or the "law and order" and "tough on crime" rhetoric of the 1990s (Haney López 2014). Populism itself has had a troubled history of subtly veiled racial appeals in the United States, as noted in Kazin's (1998) account of nineteenth century agrarian politics.

Experimental research has confirmed that multivocal claims have the capacity to effectively communicate coded meanings in the domains of religion (Albertson 2015; Calfano and Djupe 2009) and racialized political discourse (Hurwitz and Peffley 2005; Valentino, Hutchings, and White 2002; Wetts and Willer 2019; White 2007). The intent behind coded racial appeals, however, is typically not lost on the targeted minority groups or other audiences sufficiently familiar with such rhetorical strategies. In this sense, the dog-whistle metaphor has drifted from its original referent to signify coded exclusionary language in general, not just exclusionary language imperceptible to anyone but its intended audience. ${ }^{7}$

Nevertheless, the propensity of audiences to be effectively mobilized by the cues implicit in dog-whistle discourse may depend on their sharing similar worldviews and biases as the speaker (Ford 2016; Schmuck and Matthes 2015), as well as on the absence of disconfirming counter-stereotypical information (Valentino, Hutchings, and White 2002). This suggests that if populism does generate cross-domain effects with respect to nationalist beliefs, it may do so

\footnotetext{
${ }^{7}$ Even if onlookers do recognize dog-whistle discourse for what it is, its coded content gives politicians and their supporters plausible deniability if challenged: these actors are likely to reject charges of exclusionary predilections by referring to the innocuous nature of the messages in question (Haney López 2014).
} 
primarily among those respondents who are already predisposed toward out-group hostility. By increasing the salience of pre-existing out-group resentments among its target audience, subtly coded discourse can effectively channel those beliefs into support for exclusionary politics.

\section{Hypotheses}

Taken together, research on populism, out-group hostility, and dog-whistle politics suggests that populist claims may serve as subtle cues that activate people's antipathy toward ethnoracial minorities. In examining this possibility, we focus on four hypotheses. The first concerns the presence of cross-domain effects in the full sample:

Hypothesis 1 (Dog-whistle effect of right-wing populism): Respondents exposed to populist discourse targeting political elites will express less positive views of minority groups than respondents assigned to the control condition.

An aggregate effect of populism on out-group hostility, however, is likely to mask underlying moderating effects of respondents' social and political attributes. As we have argued, respondents who have been most frequently exposed to - and have favorable views of - political discourse that couples anti-elite and ethno-nationalist claims may be most likely to respond to populist dog-whistle messages. Given that exclusionary populist claims are most common on the political right, we may find the strongest cross-domain effects among Republicans:

Hypothesis 2 (Moderation of dog-whistle effect by party): Differences between the populist and control conditions in respondents' sentiments toward minority groups will be larger among Republicans than Democrats.

The above two hypotheses treat out-group antipathies as undifferentiated by aggregating sentiments toward specific target groups. This is consistent with our conceptualization of ethnonationalism as a more general phenomenon than its group-specific instantiations. Nonetheless, it is reasonable to expect some heterogeneity in the latter, given the varied emphasis placed on specific out-groups in radical-right discourse. In particular, we expect attitudes toward the five 
minority groups most frequently vilified during the Trump campaign — that is, Latinos, immigrants, Muslims, African Americans, and the non-religious (the latter two being the target of implicit exclusionary claims) — to be most susceptible to the populist treatment.

Hypothesis 3 (Heterogeneity of out-group-specific dog-whistle effects): The largest dog-whistle effects among Republican respondents should be observed for Latinos, immigrants, Muslims, African Americans, and the non-religious.

Should Hypotheses 2 and 3 be supported by the data, the cross-domain effects observed among Republicans - but not Democrats — may be attributable to the bundling of right-wing populism and ethno-nationalism in political discourse. The same result would also be consistent, however, with effects of ideology (perhaps conservatives connect various ingroup-outgroup binaries, so that anti-elite discourse evokes their anti-minority beliefs) and the attenuation of the treatment effect among Democrats due to partisanship (if Democratic respondents attributed the populist vignette to Republicans, they may have recoiled from it on the basis of their antipathy toward the Republican Party and the principles it stands for).

As an indirect test of the ideology mechanism, we include two other moderation analyses: by Trump support and by conservatism. The persistence of the observed dog-whistle effects among Trump supporters (regardless of party) provides further evidence of the discursive bundling mechanism, since it was Trump's campaign that most consistently fused populism with ethno-nationalism. On the other hand, if the effects were also observed among conservatives, regardless of party or Trump support, this would point toward an ideological mechanism that did not depend on exposure to the combination of populist and ethno-nationalist discourse. In line with our bundling argument, we expect to observe systematic moderation by Trump support but not by ideology.

Hypothesis 4 a (Moderation of out-group-specific dog-whistle effects by Trump support): Differences between the populist and control conditions in respondents' 
sentiments toward the specific out-groups listed in Hypothesis 3 will be significant among Trump supporters.

Hypothesis $4 b$ (Moderation of out-group-specific dog-whistle effects by ideology):

Differences between the populist and control conditions in respondents' sentiments toward the specific out-groups listed in Hypothesis 3 will not be significant among conservative respondents.

Finally, to isolate the partisanship mechanism - that is the possibility that the absence of dog-whistle effects among Democrats was a result of their opposition to recognizably Republican political claims — we take advantage of three features of contemporary U.S. politics: that economic populism is typically found on the political left, that it is rarely bundled by Democratic candidates with economic nationalism (for a computational text analysis of the use of economic populism by candidates in the 2004, 2008, 2012, and 2016 presidential elections, see Appendix A), and that some Democrats - especially those who self-identify as conservative - are susceptible to both economic populist and economic nationalist claims (we verify the latter proposition with our survey data). ${ }^{8}$ Based on these insights, we use Study 2 to investigate whether conservative Democrats' exposure to economic populism (i.e., moral claims that vilify economic elites and glorify working people) spills over onto chauvinist attitudes toward China, a country widely perceived as competing for American jobs, particularly in manufacturing and mobile segments of the service sector.

Consistent with our argument that the cross-domain effects of populism on nationalism are generated by the discursive bundling of these claims in political discourse, we hypothesize the following:

\footnotetext{
${ }^{8}$ This experiment also addresses the possibility that the absence of dog-whistle effects among Democrats in Study 1 could be a result of strong partisan norms against the vilification of minorities. Given that norms against denigrating other countries are less pronounced among conservative Democrats (as we show in Study 2), a lack of cross-domain effects between economic populism and chauvinism in this group would be less likely to stem from ideological constraints or social desirability effects than from the absence of the discursive bundling of these two frames by Democratic candidates.
} 
Hypothesis 5 (Discursive bundling mechanism: dog-whistle effect of left-wing economic populism): Conservative Democratic respondents exposed to populist discourse targeting economic elites will not express greater antipathy toward China compared to respondents assigned to the control condition.

\section{Data and Methods}

To test these hypotheses, we carried out two preregistered survey experiments in April 2019, in which respondents were exposed to excerpts from political speeches and asked a series of questions about their social and political attitudes, including their sentiments toward minority groups (in Study 1) and China (in Study 2). ${ }^{9}$ We recruited respondents from Amazon's Mechanical Turk in order to maximize statistical power. ${ }^{10}$ Potential participants were invited to take part in a research project investigating the persuasiveness of political messaging and were informed that their participation would consist of evaluating ideas commonly expressed by candidates in U.S. elections, as well as answering questions about their own political views. The workers were paid $\$ 0.50$ to complete the survey, with a median completion time of 6.6 minutes. We restrict our sample to respondents who are 18 years of age or older.

The data collection yielded 3,494 valid responses for the treatment conditions in Study 1 (2,039 self-identified Democrats, 1,118 Republicans, and 285 independents) and 2,062 for the treatment conditions in Study 2 (all Democrats). Another 1,717 respondents were assigned to the control condition used as a baseline for Study 1 (993 Democrats, 559 Republicans, and 132

\footnotetext{
${ }^{9}$ The experiments were preregistered on April 8, 2019 (https://bit.ly/3IfEQI8) and fielded between April 9 and May 1, 2019. For several differences between the preregistration and the final study, see Online Appendix A.

${ }^{10}$ Mechanical Turk (MTurk) has been shown to provide a satisfactory respondent pool for experimental research (Coppock 2019; Mullinix et al. 2105), particularly when caution is exercised in selecting participants and cleaning the data (Berinsky, Huber, and Lenz 2012). Following best practices, we limited our sample to workers with a high prior approval rating (>95\%) who reported residing in the United States. Participants with IP addresses outside of the U.S. or known to host bot accounts were excluded (Kennedy et al. 2018), as were participants who did not finish the survey or who did so particularly quickly or slowly (i.e., $<0.33$ or $>3$ times the median condition-specific completion time). We retained respondents who failed manipulation and attention checks (Aronow et al. 2019; Kane and Barabas 2018), but included a control for failed check status in all models.
} 
independents); 993 of these respondents who self-identified as Democrats also served as the control sample for Study 2.

In each experiment, the respondents were randomly assigned to three conditions. In the control condition, participants read a vignette that used morally neutral language to describe difficulties in direct communication between elected representatives and their constituencies. The problem was framed in technical terms, no individuals or groups were assigned blame, and a vaguely technocratic solution to the problem was proposed. The remaining conditions differed between Study 1 and Study 2.

In the populist condition in Study $1(\mathrm{~N}=1,750)$, participants were presented with a speech excerpt containing morally charged language accusing elite politicians of benefiting themselves at the expense of "the people." In the anti-immigrant condition $(\mathrm{N}=1,744)$, the vignette used incendiary language to criticize undocumented immigrants, referring not only to their legal status but also to their fundamental moral failings. The vignette for the populist condition in Study $2(\mathrm{~N}=986)$ targeted economic elites, blaming Wall Street, billionaires, and corporate leaders for rigging the political system in their own favor. Finally, the economic nationalist condition in Study $2(\mathrm{~N}=1,076)$ accused China of not playing by the rules, taking advantage of the United States, and decimating the American middle class. ${ }^{11}$

To maximize the vignettes' plausibility, we selected excerpts from actual political speeches made by U.S. political candidates, edited them for maximum impact, and combined them into the five distinct passages of equal length. Participants were informed that they were reading speeches by U.S. political candidates. The vignettes are presented in Table 1.

\footnotetext{
${ }^{11}$ We debriefed all respondents to minimize any negative consequences of exposure to the vignettes.
} 
Table 1. Vignettes used in Study 1 and Study 2

Study 1 and Study 2, Condition 1: Control

The current political system makes it really difficult for the government to connect with its constituents. The institutions are built in such a way that the government's attention is often distracted by many competing pressures, no matter how hard it tries to focus on representing the voters. To fix the system requires a lot of effort, in terms of both policy design and active participation on the part of citizens. There should be new channels of communication that would make it easier for voters to make their voices heard. At the same time, voters should be more actively engaged in reaching out to those who represent them.

Study 1, Condition 2: Anti-Government Populist Discourse

People across this country, ordinary folks with bills to pay and kids to raise, know that politicians and bureaucrats in Washington don't really work for us. The government is run by powerful elites who are fully controlled by the lobbyists and the donors. These corrupt politicians make decisions that benefit themselves and their rich friends, and ignore our wellbeing. They represent themselves only, not us. This is how hardworking American taxpayers end up being ruled by special interests in Washington. This is why we, everyday people, feel we have lost control of our own government and that Washington insiders have become our masters instead of our servants.

Study 1, Condition 3: Anti-Immigrant Discourse

The thousands of immigrants who come in illegally to steal our jobs are intolerable. They flood in, go on welfare, commit crimes, exploit our country, and pay no consequences for it. America can no longer afford to be soft on them. The government has tried to make policies that go after these immigrants, but its efforts have been limited because the current political system makes it really difficult to create real change. The institutions are built in such a way that the government's attention is often distracted by many competing pressures, no matter how hard it tries to focus on the issues that voters care about most.

Study 2, Condition 2: Economic Populist Discourse

The greed of Wall Street and corporate America is destroying the lives of everyday folks like us. Throughout history, the billionaires and corporate leaders have rigged our government in their favor, leaving us far behind. Our voices have been drowned out by powerful corporations and big finance. The business elites get whatever they want from policymakers, we get absolutely nothing. What kind of democracy are we living in? Democracy in our country is for the wealthy few, and ordinary taxpayers like us, people who work hard to make ends meet, are being crushed by the top one percent. Their corporate interests dominate everything; our interests are ignored.

Study 2, Condition 3: Economic Nationalist Discourse

People across this country, ordinary folks with bills to pay and kids to raise, are suffering because China and other countries are not playing by the rules. They are taking our jobs by cutting labor standards, stealing our intellectual property, and dumping their cheap products on the American market. They are taking the dollar hostage and they are trying to change global trade rules so that they can keep taking advantage of us. China gets richer and richer while the American middle class collapses. This cannot go on anymore. We need to stand up for hard-working Americans by negotiating trade deals that benefit us, not other countries.

It is important to note that the vignettes' varied intensity is intentional, not only because it

reflects real political discourse, but also because it facilitates the comparisons in our analysis. For

instance, the strong language in the anti-immigrant condition in Study 1 serves as a baseline for

examining the magnitude of possible dog-whistle effects in the right-wing populism condition.

The tone of the economic nationalism condition in Study 2, on the other hand, is milder, to 
prevent socially desirable responses by Democratic respondents who may be averse to explicitly inegalitarian frames. Despite these differences, our vignettes represent relatively modest primes compared to the intensity and frequency of routine populist, ethno-nationalist, and economic nationalist claims in contemporary U.S. political discourse. Therefore, any effects we observe in our study are likely to underestimate the actual consequences of such claims outside of the experimental setting.

After reading the vignettes, respondents answered manipulation check questions and then completed a survey concerning their social and political attitudes, including their sentiments toward out-groups (i.e., ethnic, racial, immigrant, and religious minorities in Study 1 and China in Study 2). The latter were measured using feeling thermometers ranging from 1 to 100 . To construct the composite out-group antipathy variable for Study 1, we calculated the mean of thermometer scores measuring feelings toward Latinos, African Americans, Asian Americans, Muslims, Jews, documented immigrants, undocumented immigrants, and the non-religious. We also consider these items separately to test Hypotheses 3 and 4 .

Prior to the experimental treatment, respondents were asked a range of demographic questions, including their partisan identification, approval of Donald Trump's presidency, and self-reported political ideology. We use these variables to test the hypothesized moderating effects. ${ }^{12}$ Table 2 reports descriptive statistics for both studies. For a summary of key variables by condition, see Appendix B.

\footnotetext{
${ }^{12}$ The robustness of the moderation analysis is a function of respondents' random assignment to the experimental conditions. Give the non-representativeness of our data, however, we are only able to make claims about the heterogeneity of the experimental effects within our sample and cannot generalize beyond it.
} 
Table 2. Descriptive statistics for Study 1 and Study 2

\begin{tabular}{lcc}
\hline Variable & $\begin{array}{c}\text { Study } 1(\mathrm{~N}=5,211) \\
\text { Proportion / mean }\end{array}$ & $\begin{array}{c}\text { Study 2 }(\mathrm{N}=3,055) \\
\text { Proportion / mean }\end{array}$ \\
\hline Gender: Female & 0.55 & 0.59 \\
Education: High school or less & 0.27 & 0.26 \\
Education: Associate or college degree & 0.58 & 0.57 \\
Education: Graduate degree & 0.16 & 0.17 \\
One or both parents born in the U.S. & 0.89 & 0.88 \\
Party: Democrat & 0.59 & 1 \\
Party: Republican & 0.33 & 0 \\
Party: Independent or other & 0.08 & 0 \\
Passed manipulation checks & 0.97 & 0.98 \\
Age (mean) & 37.7 & 36.7 \\
\hline
\end{tabular}

\section{Results}

Study 1: Right-Wing Populism and Sentiments Toward Minority Groups

The analysis of Study 1 data proceeds in three steps. First, we compare the mean feeling thermometer ratings of minority groups across the three conditions in the sample as a whole.

This tests Hypothesis 1, whether populism targeting political elites spills over onto exclusionary nationalism. Second, we use regression models with interaction terms to examine the moderating effects of party identification. This allows us to evaluate Hypothesis 2, which posited that populism's dog-whistle effects may be concentrated among Republicans, who have been most frequently exposed to, and are most favorable toward, political discourse that connects antielitism with racial resentment. Third, we disaggregate the composite dependent variable into its constituent out-group feeling thermometer items and compare their mean values between the experimental and control conditions separately for Republicans, Trump supporters (i.e., those who express approval for Donald Trump's performance as president), and conservatives. This allows us to evaluate Hypotheses 3, 4a, and 4b. 
Figure 1. Sentiments toward minorities by condition, Study 1.

75
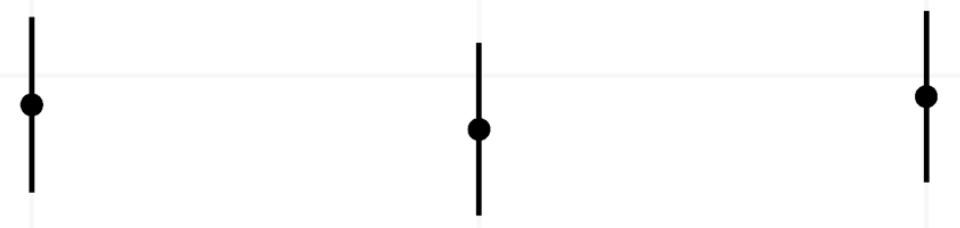

65

Control Anti-Gov. Populism Ethno-Nationalism

Figure 1 presents the means and standard errors of the composite out-group ratings across the three conditions (control, right-wing populist, and anti-immigration). ${ }^{13}$ In the control condition, respondents rated minority groups moderately favorably, at 67.2 on a 100-point scale. ${ }^{14}$ The means for the anti-immigrant and right-wing populist conditions were similar, at 67.3 and 66.9, respectively. Contrary to Hypothesis 1, our respondents did not, on average, exhibit greater antipathy toward minority groups when exposed to anti-immigrant or anti-elite political language than to morally neutral language.

It is possible, however, that these aggregate results mask underlying sample heterogeneity, as posited in Hypothesis 2. In particular, Democrats in the sample may recoil from

\footnotetext{
${ }^{13}$ For complete regression results of Study 1 and 2, see Appendix C.

${ }^{14}$ All models control for respondents' successful completion of manipulation and attention checks. The conditionspecific means reported in the text average over the values of the manipulation/attention check dummy variable.
} 
political rhetoric they perceive as characteristic of Republican politicians or, alternatively, Democrats' egalitarian commitments may dampen their susceptibility to anti-minority priming effects, resulting in weaker (or even opposite) treatment effects compared to Republican respondents. ${ }^{15}$ To examine potential party moderation effects, we regressed the composite outgroup rating variable on experimental condition assignment, party identification, a condition-byparty interaction term, and a manipulation check dummy variable. The results are presented in Figure 2.

Figure 2. Sentiments toward minorities by condition and party, Study 1.

80

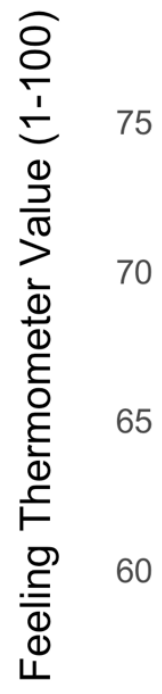

55
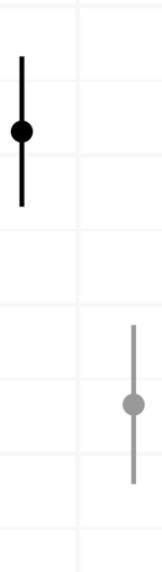

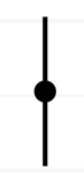

(1)

0 5

Control
Anti-Gov. Populism

Democrats - Republicans

\footnotetext{
${ }^{15} 88.1$ percent of respondents - and 91.8 percent of Democrats - exposed to the anti-immigrant vignette attributed it to a Republican politician. Respondents, however, were more equivocal about the party sponsor of the populist vignette: 49.9 percent attributed it to a Democrat, 20.9 percent to a Republican, and 29.2 were unsure (Democrats were particularly likely to think the speaker was a Democrat, at 59.3 percent).
} 
The difference between party-specific feeling thermometer means in the control condition demonstrates that, on average, Republican respondents held more negative attitudes toward minorities (61.6) than did Democrats (70.8). This difference becomes even more marked, however, in the two treatment conditions. Exposure to anti-immigrant language decreased Republicans' evaluation of minorities by 2.8 percent (or 0.08 standard deviations), to 59.9 , compared to a 1.8 percent increase (to 72.1) among Democrats. Exposure to populist rhetoric targeting political elites — devoid of any ethno-nationalist content—had an even stronger effect: Republicans' evaluation of minorities decreased by 4.7 percent ( 0.14 standard deviations) between the control and populism conditions, to 58.7 (compared to 72.6 among Democrats). The difference in the feeling thermometer means between the populist and control conditions among Republicans was statistically significant at the $\mathrm{p}<0.05$ level, whereas the differences between the anti-immigrant and control conditions and between the anti-immigrant and populist conditions did not reach statistical significance.

These findings demonstrate that populism does serve as a dog-whistle for ethnonationalism, but, in line with Hypothesis 2, this effect is moderated by partisan identity: Republicans experience greater antipathy toward out-groups when exposed to critiques of political elites, whereas Democrats do not. Next, we examine possible effect heterogeneity for the group-specific feeling thermometer measures, as well as moderation effects by Trump support and ideology. The results are visualized in Figure 3.

The first thing to notice is that the cross-domain effects captured by the composite dependent variable in the previous analysis persist across a number of target out-groups. Largely consistent with Hypothesis 3, Republicans exposed to a populist message reported significantly lower levels of warmth toward Latinos, African Americans, the non-religious, documented 
immigrants, and Asian Americans, in descending order of treatment effect size (ranging from 3.7 to 2.8 points on a 100 -point scale — or from 0.16 to 0.12 standard deviations). This is consistent with our characterization of the cross-domain effects as involving populism and ethnonationalism in general: the antipathies generated by the populist vignettes span racial, ethnic, and religious groups, including those that had been stigmatized only implicitly by Donald Trump's campaign (e.g., African Americans) or who had not been the focus of his exclusionary discourse (e.g., Asian Americans ${ }^{16}$ ). The effects of exposure to the anti-immigrant vignette stand in contrast to these results: although the treatment effects were sizably negative for Latinos, Jews, and undocumented immigrants, none of them reached statistical significance. This suggests that populism may in fact be more effective at mobilizing broad out-group antipathies than exclusionary discourse targeting specific minorities.

There are two notable exceptions to the hypothesized effects of populism on out-group attitudes among Republicans: the effects are non-significant for undocumented immigrants and Muslim Americans, groups that are highly stigmatized in contemporary politics. One plausible explanation for these null results is that the extensive pre-treatment of Republican respondents outside of the experimental setting with anti-Muslim and anti-immigrant political discourse has resulted in floor effects that make evaluations of these two groups less susceptible to further manipulation. This intuition is supported by the finding that among Republican respondents in the control condition, undocumented migrants and Muslims have the lowest adjusted mean feeling thermometer values of all the out-groups in the study, at 33.3 and 50.1 out of 100 , respectively.

\footnotetext{
${ }^{16}$ Trump did stigmatize Asian Americans, but only after the outbreak of the COVID-19 pandemic in early 2020, not in his 2016 campaign. Our data precede the pandemic by almost one year.
} 
That populism increased Republicans' antipathies toward multiple out-groups after a single exposure to a brief vignette speaks to the potential strength of cross-domain effects. Indeed, as noted, the attitudinal consequences of the populism treatment were stronger and more extensive than those of incendiary anti-immigrant discourse, the political relevance of which is well documented (e.g., Matthes and Schmuck 2017; Schemer 2012). Such effects are likely to be even greater in the context of routine exposure to more extensive populist messaging by actual political campaigns.

As a further assessment of the magnitude of the observed treatment effects, we compared them to associations between feeling thermometer responses and salient political issue preferences in the 2016 American National Election Study, focusing on sentiments toward Latinos and African Americans (see Appendix D). We take this approach because differences in the strength of agreement with specific statements about minority groups are likely to be more intuitive to readers than differences in abstract feeling thermometer scores. The results suggest that the effect sizes in our experiment, conservative though they are, are meaningful. In the ANES data, the same difference in sentiments toward Latinos as that observed among Republican respondents in our study's control and populist conditions increases the probability of favoring immigration limits by 4.1 percent and of believing that Hispanics are lazy by 11.9 percent. ${ }^{17}$ The corresponding difference in sentiments toward African Americans increases the probability of opposing government help to Blacks by 8.3 percent and of believing that Blacks are lazy by 6.6 percent.

In the above analyses, exposure to anti-elite rhetoric had heterogeneous effects on outgroup sentiments among Democrats and Republicans. This raises the question of what

\footnotetext{
17 These results are based on predictive margins among respondents in the 2016 ANES Pilot Survey with covariate values set to mean age, male, college education, and Republican.
} 
mechanisms are driving the partisan difference. On the Democratic side, we have suggested that negative partisanship or egalitarian commitments may have dampened the experimental effects. That nearly 92 percent of Democratic respondents attributed the anti-immigration vignette to a Republican candidate (see footnote 14) is consistent with the former possibility. However, the lack of consensus among Democrats on the party sponsor of the populist vignette and their broad agreement with its content (85.2 percent endorsed it, compared to 13.6 for the anti-immigrant vignette) suggests that the latter mechanism may be at play as well.

Among Republicans, it is possible that the association between populism and antiminority sentiments is a result of discursive bundling or of ideological predilections, as posited in Hypotheses $4 \mathrm{a}$ and $4 \mathrm{~b}$. The evidence, presented in Figure 3, appears more consistent with the former scenario: Trump approval (regardless of respondents' partisan identification) is an even stronger moderator of the group-specific cross-domain effects than Republican self-identification (particularly for sentiments toward Latinos, Asian Americans, and the non-religious), whereas political ideology does not exhibit any significant moderating effects. ${ }^{18}$

\section{Study 2: Left-Wing Populism and Sentiments Toward China}

Next, we examine the impact of economic populism on chauvinism among Democratic respondents to ascertain whether left-wing populism behaves similarly to right-wing populism and to indirectly test the discursive bundling mechanism as a driver of the cross-domain effects observed in Study 1. If discursive bundling is indeed responsible for the latter, its absence in recent Democratic campaigns (see the text analysis results in Appendix A) should inhibit the activation of chauvinist beliefs among Democrats following exposure to economic populist

\footnotetext{
${ }^{18}$ We thank a reviewer for suggesting this interpretation of the ideology results.
} 
Figure 3. Group-specific sentiments by condition, party, Trump support, and ideology, Study 1.

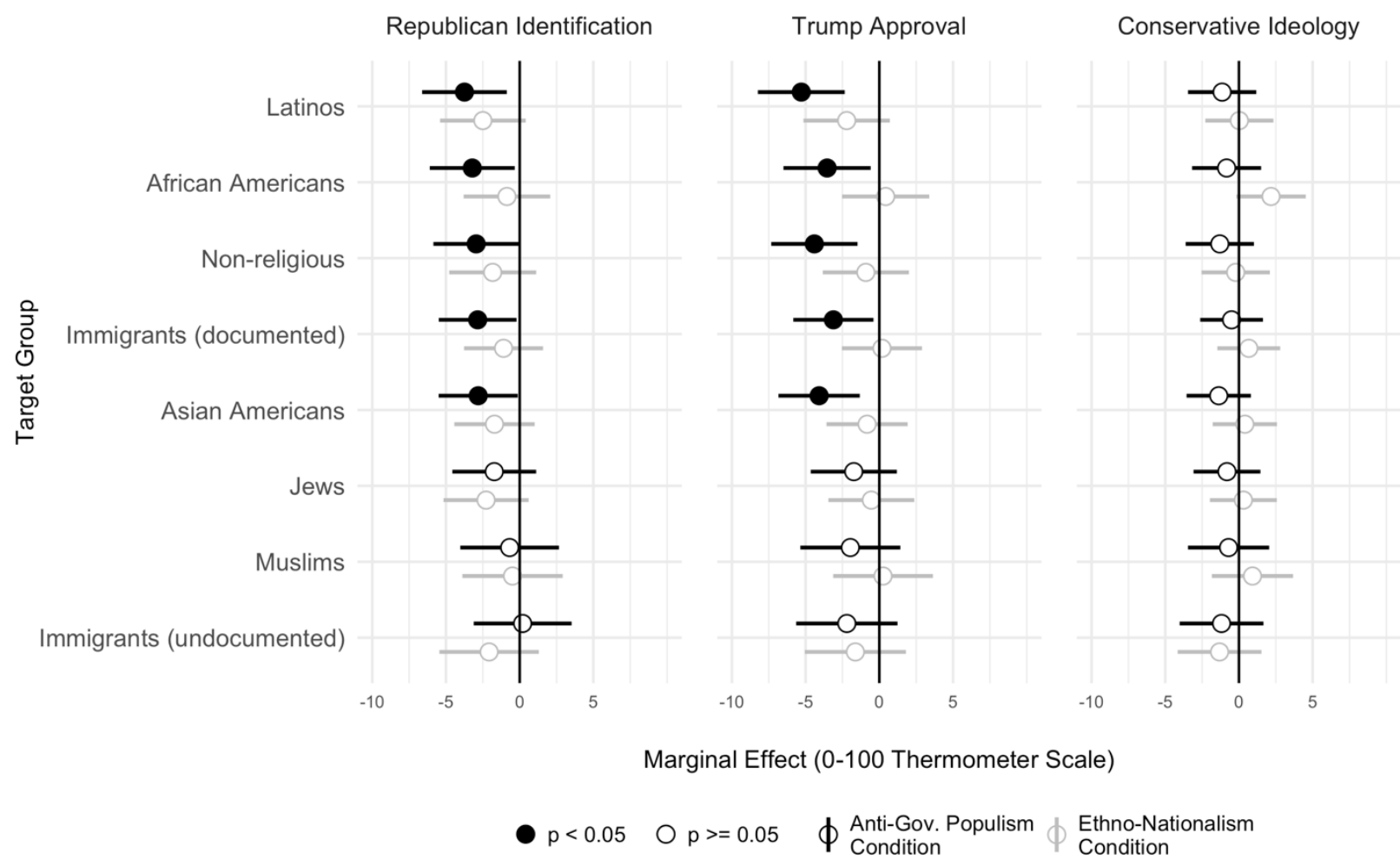

rhetoric. In order for this design to isolate the bundling mechanism, however, the respondents must be susceptible to the activation of both economic populism and chauvinism in the first place. For this reason, our analysis focuses on conservative Democrats, who-as we will demonstrate - meet these criteria.

Figure 4 reports disagreement with the economic populist and economic nationalist vignettes (the latter being explicitly anti-China) among Democrats, disaggregated by ideology. ${ }^{19}$ Not surprisingly, few Democrats, both liberal and conservative (1.9 percent and 6 percent, respectively), are opposed to economic populist claims, which are common on the left. The response distribution for the economic nationalism vignette shows higher levels of disagreement,

\footnotetext{
${ }^{19} \mathrm{We}$ dichotomize the 10-point ideology scale at 2.5. For the relationship between the full continuous ideology variable and sentiments toward China, see Appendix E.
} 
Figure 4. Disagreement with economic nationalist and economic populist vignettes, Study 2.

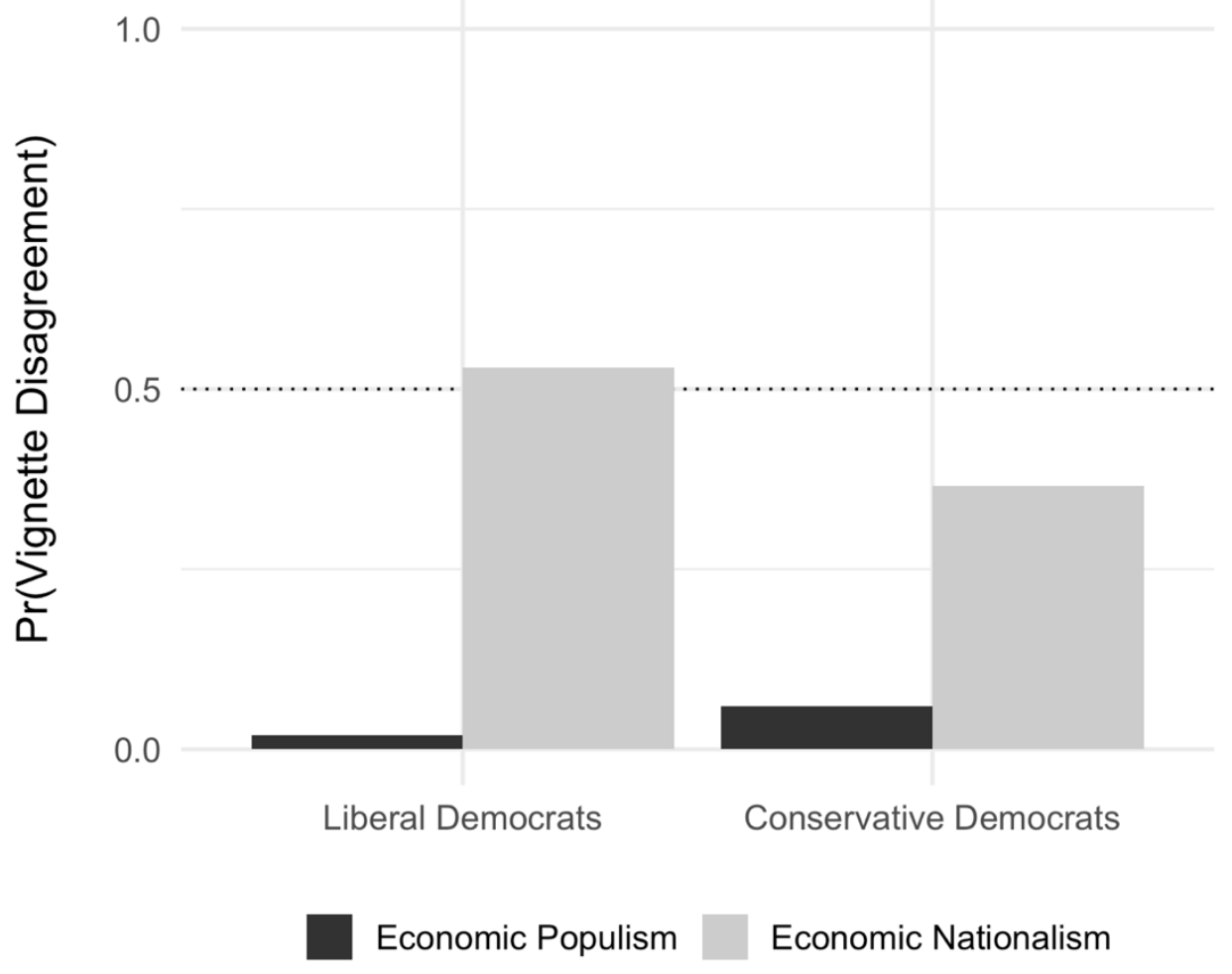

averaging 42.4 percent in the Democratic sample as a whole. Here, however, ideology plays an important moderating role: whereas the majority of liberal Democrats disagree with the vignette (53 percent), the same is true of only a minority of conservative Democrats (36.6 percent). Consequently, we can assume that most conservative Democrats in our sample are in principle susceptible to both economic populism and economic nationalism, while most liberal Democrats are likely to be swayed solely by the former. The questions that remain are (a) whether conservative Democrats display greater antipathy toward countries associated with the offshoring of U.S. jobs (and other negative economic outcomes) when exposed to economic nationalism, and if so, (b) whether economic populism produces the same chauvinistic effects despite not having been routinely bundled with economic nationalism by Democratic politicians (per Hypothesis 3, we expect not to observe such cross-domain effects). 
Figure 5. Sentiments toward China by condition and party, Study 2.

60
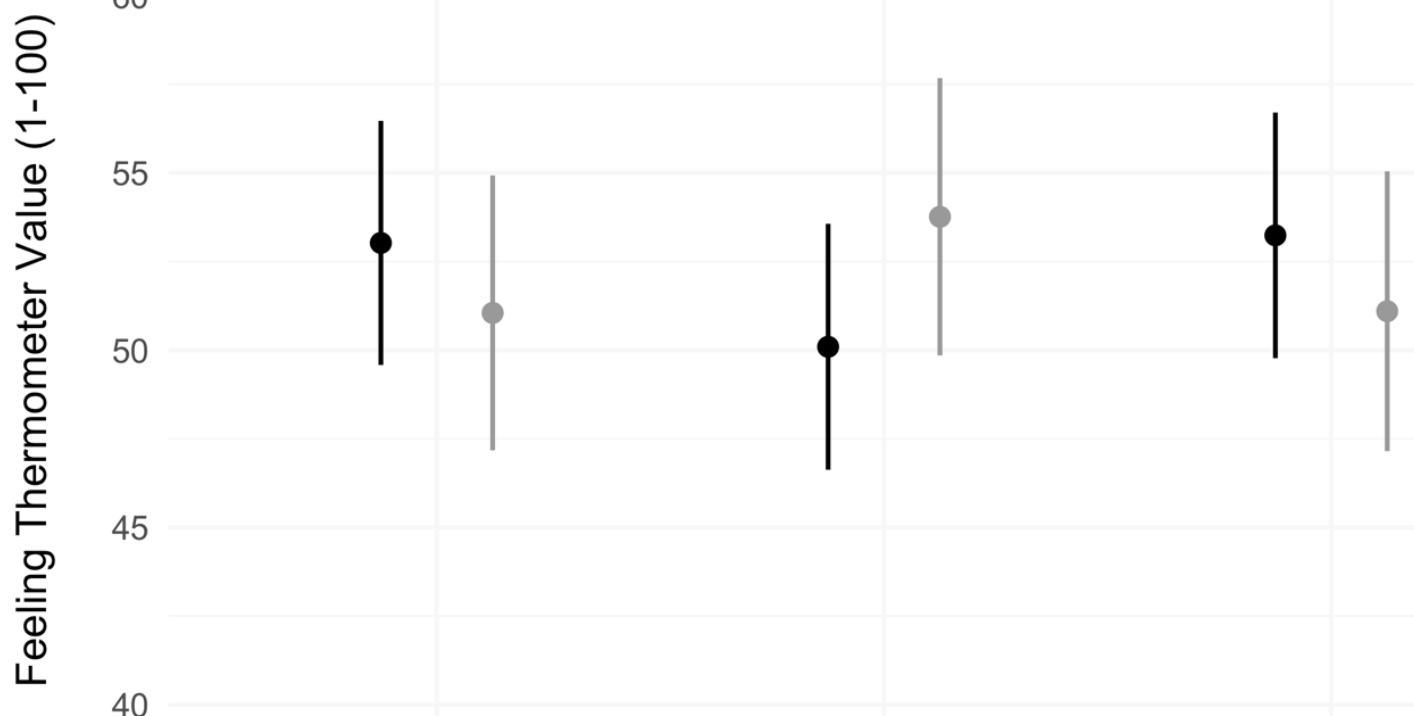

Control

Economic Nationalism

Economic Populism

- Conservative Democrats - Liberal Democrats

Figure 5 presents the mean China feeling thermometer values for Democrats across the control, economic nationalism, and economic populism conditions, broken up by liberal and conservative ideology. The contrasting results across the two subsamples are striking. Exposure to economic nationalist discourse reduces positive sentiment toward China among conservative Democrats by 5.5 percent (or by 0.12 standard deviations), from 53 to 50.1 on a 100 -point scale. There is no significant difference, however, between the control and economic nationalism condition among liberal Democrats. This confirms our earlier intuition, based on levels of agreement with the experimental vignette, that the conservative Democrats in our sample are uniquely susceptible to the effects of economic nationalism on chauvinist attitudes. Given their overwhelming support for economic populism, they should also be prone to populist priming. And yet, the results for the economic populism condition show no difference compared to the control condition in the intensity of anti-China sentiments among conservative or liberal 
Democrats ( $p=0.884$ and $p=0.979$, respectively). Consistent with Hypothesis 3 , economic populism does not appear to serve as a dog-whistle for economic nationalism among Democrats, not because Democrats (at least conservative ones) are immune to chauvinist sentiments, but rather because populism and nationalism have not been routinely bundled in Democratic political discourse.

\section{Discussion}

This paper has demonstrated that exposure to populist claims targeting political elites can activate respondents' ethno-nationalist sentiments, increasing their antipathy toward minority groups (in Study 1). This effect is limited, however, to Republican respondents and Trump supporters in our sample, leading us to posit that the partisan moderation effect is a result of the bundling of populism and nationalism in Republican political discourse. To test this claim, in Study 2, we examined the relationship between economic populism and chauvinism (i.e., the tendency to disparage countries associated with the offshoring of U.S. jobs), ingroup-outgroup distinctions that are rarely discursively coupled on the left. We focused on conservative Democratic respondents, who reported low levels of disagreement with both the economic nationalist and economic populist vignettes, with the former singling out China in explicitly moral terms as an economic threat to the United States. When exposed to economic nationalist claims, these respondents reported significantly lower favorability toward China (liberal Democrats were unaffected). We found no evidence, however, of economic populism serving as a dog-whistle for chauvinism among conservative Democrats: their sentiments toward China did not differ between the control and economic populism conditions, remaining at levels similar to those of their liberal co-partisans. 
Given that populism and chauvinistic economic nationalism had not been explicitly linked in recent Democratic campaigns nor do such claims frequently co-occur in mainstream media, we conclude that it is the absence of issue bundling in public discourse that precludes conservative Democratic respondents from exhibiting strong associations between these sentiments. This stands in contrast to the routine invocation of both populism targeting political elites and ethno-nationalism by the Trump campaign and right-wing media. The Republican bundling of populism and nationalism appears to have effectively turned anti-elite claims into proxies for ethnoracial resentment.

The notion that attitudes must be connected by an authority, such as a political party, in order to exhibit constraint (that is, strong association) at the individual level can be traced back to the seminal work of Converse (1964), and its subsequent elaboration by Martin (2002). This approach argues that there is no inherent logical connection between most beliefs and that instead, beliefs become cognitively associated once people observe their routine co-occurrence in the discourse and practice of high-status individuals in their social groups - and all the more so when such associations are institutionalized by authoritative organizations. Once such patterns are sufficiently reinforced, departures from them are rare, because the decoupling of tightly coupled beliefs is likely to generate cognitive dissonance and be censured within ideologically homophilous social networks (Goldberg and Stein 2018; Martin 2002).

Our results are consistent with this perspective, but they suggest that constraint itself is insufficient for producing cross-domain effects. Republican respondents in Study 1 tended to hold both politically populist and ethno-nationalist views, just as most conservative Democratic respondents in Study 2 held both economic populist and chauvinist views; yet, only among the Republican respondents in Study 1 did populism activate out-group antipathies. If these 
divergent results are in fact a consequence of the bundling of populism and nationalism by Republican politicians and media personalities and the absence of such bundling by their Democratic counterparts, this would suggest that existing belief constraint must be accompanied by joint belief activation by authority figures in order to generate cross-domain effects. In other words, it is not sufficient that both beliefs are co-present in people's cognitive schemas- the mutual substitutability of the public frames corresponding to those beliefs must also be encoded in cultural scripts that are repeatedly performed by actors in positions of cultural authority. This would be consistent with the claim in the political articulation literature that parties do not merely enact the views of the public but actively construct and naturalize political cleavages and associated cultural frames and policy demands (De Leon, Desai, and Tuğal 2009).

In addition to this general theoretical insight, our study makes two contributions specific to research on radical politics. First, we show that the analytical distinction between populism and nationalism made in recent work (Bonikowski 2017; Mudde 2007; Rooduijn and Akkerman 2017) can be operationalized in empirical research, so that the distinct effects of each phenomenon and the relationship between them can be systematically evaluated. Isolating populism and nationalism in experimental vignettes allowed us to demonstrate the tight coupling between these ideational constructs in one sub-sample and their independence in another.

Second, our findings suggest that while ethno-nationalist frames may be particularly prevalent in right-wing discourse (Judis 2016; Mudde and Kaltwasser 2013), supporters of leftwing parties are not immune to the activation of exclusionary beliefs. Through brief exposure to an economic nationalist vignette, conservative Democrats in our sample were easily swayed toward greater antipathy toward China. This finding highlights the importance of expanding the definition of nationalism in research on radical politics beyond nativism. Chauvinism may be an 
equally important dimension of people's construals of the nation (Bonikowski 2016; De Figuerido and Elkins 2003; Kosterman and Feschbach 1989; Li and Brewer 2004) and its impact may be particularly marked in left-wing politics, because negative assessments of other countries may be less prone than ethno-nationalism to direct conflict with egalitarian conceptions of domestic inter-group relations. If left-wing parties were to combine economic nationalist appeals with a populist critique of economic elites, effectively fusing these two dispositions in voters' minds, the resulting discursive mix could be as electorally effective as it would be detrimental to measured policy debate, and perhaps even to the treatment of domestic minorities (e.g., ChineseAmericans in the case of anti-China sentiments).

Although our study is not without limitations - we rely on non-representative survey samples, for instance, and are able to only indirectly test the discursive bundling mechanism—it marks an important starting point for research on the ideational consequences of populist discourse. Rather than assuming populism and nationalism to be either conceptually coterminous or empirically inseparable, our paper demonstrates the possibility of precisely defining and operationalizing these constructs and rigorously studying their relationship. It is our hope that future research will build on this approach to better understand how populist discourse shapes and activates political attitudes, mobilizes political behavior, and interacts with partisan commitments. Such work can serve as an important complement-and perhaps even a corrective - to the large party-based literature on the causes of populist electoral success and the consequences of populist governance. 


\section{References}

Abascal, Maria. 2015. "Us and Them: Black-White Relations in the Wake of Hispanic Population Growth." American Sociological Review 80(4):789-813.

Abrajano, Marisa, and Zoltan Hajnal. 2015. White Backlash: Immigration, Race, and American Politics. Princeton, NJ: Princeton University Press.

Akkerman, Agnes, Cas Mudde, and Andrej Zaslove. 2014. "How Populist Are the People? Measuring Populist Attitudes in Voters." Comparative Political Studies 47(9):1324-53.

Akkerman, Tjitske, and Sarah L. de Lange. 2012. "Radical Right Parties in Office: Incumbency Records and the Electoral Cost of Governing." Government and Opposition 47(4):574-596.

Albertson, Bethany L. 2015. "Dog-Whistle Politics: Multivocal Communication and Religious Appeals." Political Behavior 37(1):3-26.

Aronow, Peter M., Jonathon Baron, Lauren Pinson. 2019. “A Note on Dropping Experimental Subjects who Fail a Manipulation Check.” Political Analysis 27(4):572-89.

Art, David. 2007. "Reacting to the Radical Right: Lessons from Germany and Austria." Party Politics 13(3):331-349.

Aslanidis, Paris. 2016. "Is Populism an Ideology? A Refutation and a New Perspective." Political Studies 64(1):88-104.

Berezin, Mabel. 2009. Illiberal Politics in Neoliberal Times: Culture, Security and Populism in the New Europe. New York: Cambridge University Press.

Berinsky, Adam J., Gregory A. Huber, and Gabriel S. Lenz. 2012. "Evaluating Online Labor Markets for Experimental Research: Amazon.com's Mechanical Turk." Political Analysis 20(3):351-68.

Blumer, Herbert. 1958. "Race Prejudice as a Sense of Group Position." The Pacific Sociological Review 1:3-7.

Bobo, Lawrence D. 1999. "Prejudice as Group Position: Microfoundations of a Sociological Approach to Racism and Race Relations.” Journal of Social Issues 55(3):445-72.

Bobo, Lawrence, and Vincent L. Hutchings. 1996. "Perceptions of Racial Group Competition: Extending Blumer's Theory of Group Position to a Multiracial Social Context." American Sociological Review 61(6):951-72.

Bonikowski, Bart. 2016. "Nationalism in Settled Times." Annual Review of Sociology 42(1):42749.

Bonikowski, Bart. 2017. "Ethno-Nationalist Populism and the Mobilization of Collective Resentment.” The British Journal of Sociology 68(S1):S181-213.

Bonikowski, Bart, and Paul DiMaggio. 2016. "Varieties of American Popular Nationalism." American Sociological Review 81(5):949-80.

Bonikowski, Bart, Yuchen Luo, and Oscar Stuhler. 2022. "Politics as Usual? Antecedents of Radical-Right Frames in U.S. Electoral Discourse." SocArxiv. https://osf.io/preprints/socarxiv/uhvbp/. 
Bonikowski, Bart, and Noam Gidron. 2016. "The Populist Style in American Politics: Presidential Campaign Rhetoric, 1952-1996.” Social Forces 94(4):1593-621.

Bonilla-Silva, Eduardo. 1997. "Rethinking Racism: Toward a Structural Interpretation." American Sociological Review 62(3):465-80.

Bonilla-Silva, Eduardo. 2006. Racism Without Racists: Color-Blind Racism and the Persistence of Racial Inequality in the United States. New York: Rowman \& Littlefield Publishers.

Brubaker, Rogers. 2002. "Ethnicity Without Groups.” European Journal of Sociology 43(2): 163-189.

Calfano, Brian R., and Paul A. Djupe. 2009. "God Talk: Religious Cues and Electoral Support." Political Research Quarterly 62(2):329-39.

Caraballo, Krystlelynn. 2020. "From Victim to Criminal and Back: The Minority Threat Framework's Impact on Latinx Immigrants.” City \& Community 19(2):315-22.

Converse, Philip E. 1964. "The Nature of Belief Systems in Mass Publics." Pp. 206-61 in Ideology and Discontent, edited by David E. Apter. New York: Free Press.

Coppock, Alexander. 2019. "Generalizing from Survey Experiments Conducted on Mechanical Turk: A Replication Approach.” Political Science Research and Methods 7(3):613-628.

Craig, Maureen A., and Jennifer A. Richeson. 2014. 'On the Precipice of a 'Majority-Minority' America: Perceived Status Threat from the Racial Demographic Shift Affects White Americans' Political Ideology.” Psychological Science 25(6):1189-97.

Cramer, Katherine J. 2016. The Politics of Resentment: Rural Consciousness in Wisconsin and the Rise of Scott Walker. Chicago, IL: University of Chicago Press.

Dai, Yaoyao and Alexander Kustov. 2022. "When Do Politicians Use Populist Rhetoric? Populism as a Campaign Gamble.” Political Communication. Forthcoming.

de Lange, Sarah Leah. 2012. "New Alliances: Why Mainstream Parties Govern With Radical Right-Wing Populist Parties.” Political Studies 60(4):999-18.

De Leon, Cedric, Manali Desai, and Cihan Tuğal. 2009. "Political Articulation: Parties and the Constitution of Cleavages in the United States, India, and Turkey." Sociological Theory 27(3):193-219.

Deegan-Krause, Kevin, and Tim Haughton. 2009. "Toward a More Useful Conceptualization of Populism: Types and Degrees of Populist Appeals in the Case of Slovakia." Politics \& Policy 37(4):821-41.

Dennison, James, and Andrew Geddes. 2019. "A Rising Tide? The Salience of Immigration and the Rise of Anti-Immigration Political Parties in Western Europe." The Political Quarterly 90(1):107-16.

Fallend, Franz, and Reinhard Heinisch. 2015 "Collaboration as Successful Strategy Against Right-wing Populism? The Case of the Centre-right Coalition in Austria, 2000-2007." Democratization 23(2):324-344.

Ford, Robert. 2016. "Who Should We Help? An Experimental Test of Discrimination in the British Welfare State.” Political Studies 64(3):630-50. 
Freeden, Michael. 1996. Ideologies and Political Theory: A Conceptual Approach. Oxford, UK: Oxford University Press.

Gidron, Noam, and Peter Hall. 2017. "The Politics of Social Status: Economic and Cultural Roots of the Populist Right." The British Journal of Sociology 68(S1):S57-S84.

Goldberg, Amir and Sarah K. Stein. 2018. "Beyond Social Contagion: Associative Diffusion and the Emergence of Cultural Variation." American Sociological Review 83(5):897-932.

Haney López, Ian. 2014. Dog Whistle Politics: How Coded Racial Appeals Have Reinvented Racism and Wrecked the Middle Class. New York: Oxford University Press.

Hawkins, Kirk A., and Cristóbal R. Kaltwasser. 2017. "The Ideational Approach to Populism." Latin American Research Review 52(4):513-28.

Hopkins, Daniel J. 2021. "The Activation of Prejudice and Presidential Voting: Panel Evidence from the 2016 US Election." Political Behavior 43(2):663-86.

Hurwitz, Jon, and Mark Peffley. 2005. "Playing the Race Card in the Post-Willie Horton Era: The Impact of Racialized Code Words on Support for Punitive Crime Policy." Public Opinion Quarterly 69(1):99-112.

Ivarsflaten, Elisabeth. 2008. "What Unites Right-Wing Populists in Western Europe? ReExamining Grievance Mobilization Models in Seven Successful Cases." Comparative Political Studies 41(1):3-23.

Jansen, Robert S. 2011. "Populist Mobilization: A New Theoretical Approach to Populism." Sociological Theory 29(2): 75-96.

Judis, John B. 2016. The Populist Explosion: How the Great Recession Transformed American and European Politics. New York: Columbia Global Reports.

Kaltwasser, Cristobal R., and Paul Taggart. 2015. "Dealing with Populists in Government: a Framework for Analysis." Democratization 23(2):201-20.

Kane, John V., and Jason Barabas. 2018. "No Harm in Checking: Using Factual Manipulation Checks to Assess Attentiveness in Experiments." American Journal of Political Science 63(1):234-49.

Kazin, Michael. 1998. The Populist Persuasion: An American History. Ithaca, NY: Cornell University Press.

Kennedy, Ryan, Scott Clifford, Tyler Burleigh, Ryan Jewell, and Philip Waggoner. 2018. "The Shape of and Solutions to the MTurk Quality Crisis." Social Science Research Network. https://ssrn.com/abstract $=3272468$

Kinder, Donald R., and Cindy D. Kam. 2010. Us Against Them: Ethnocentric Foundations of American Opinion. Chicago, IL: University of Chicago Press.

Kustov, Alexander, Dillon Laaker, and Cassidy Reller. 2021. "The Stability of Immigration Attitudes: Evidence and Implications." The Journal of Politics 83(4):1478-94.

Laclau, Ernesto. 2005. On Populist Reason. London, UK: Verso.

Loveman, Mara. 1999. “Is ‘Race’ Essential?” American Sociological Review 64(6):891-8. 
Madrid, Raúl L. 2008. “The Rise of Ethnopopulism in Latin America.” World Politics 60(3):475-508.

Martin, John L. 2002. "Power, Authority, and the Constraint of Belief Systems." American Journal of Sociology 107(4):861-904.

Matthes, Jörg, and Desirée Schmuck. 2017. The Effects of Anti-Immigrant Right-Wing Populist Ads on Implicit and Explicit Attitudes: A Moderated Mediation Model. Communication Research 44(4):556-581.

McVeigh, Rory, and Kevin Estep. 2019. The Politics of Losing: Trump, the Klan, and the Mainstreaming of Resentment. New York: Columbia University Press.

Mendelberg, Tali. 2001. The Race Card: Campaign Strategy, Implicit Messages, and the Norm of Equality. Princeton, NJ: Princeton University Press.

Messing, Solomon, Maria Jabon, and Ethan Plaut. 2015. "Bias in the Flesh: Skin Complexion and Stereotype Consistency in Political Campaigns." Public Opinion Quarterly 80(1):44-65.

Minkenberg, Michael. 2001 "The Radical Right in Public Office: Agenda-Setting and Policy Effects." West European Politics 24(4):1-21.

Miriliovic, Nikola, and Myunghee Kim. 2017. "Ideology and Threat Perceptions: American Public Opinion toward China and Iran.” Political Studies 65(1):179-98.

Moffitt, Benjamin, and Simon Tormey. 2013. "Rethinking Populism: Politics, Mediatisation and Political Style.” Political Studies. 62(2):381-397.

Mudde, Cas. 2007. Populist Radical Right Parties in Europe. New York: Cambridge University Press.

Mudde, Cas, and Kaltwasser, Cristóbal R., 2013. "Exclusionary vs. Inclusionary Populism: Comparing Contemporary Europe and Latin America." Government and Opposition 48(2):147-174.

Mullinix, Kevin J., Thomas J. Leeper, James N. Druckman, and Jeremy Freese. 2015. “The Generalizability of Survey Experiments." Journal of Experimental Political Science 2(2):109-38.

Oesch, Daniel. 2008. “Explaining Workers' Support for Right-Wing Populist Parties in Western Europe: Evidence from Austria, Belgium, France, Norway, and Switzerland.” International Political Science Review 29(3):349-73.

Oliver, J. Eric, and Wendy M. Rahn. 2016. "Rise of the Trumpenvolk Populism in the 2016 Election." The ANNALS of the American Academy of Political and Social Science 667(1):189-206.

Olzak, Susan. 1989. "Labor Unrest, Immigration, and Ethnic Conflict in Urban America, it 18801914." American Journal of Sociology 94(6):1303-1333.

Omi, Michael, and Howard Winant. 2014. Racial Formation in the United States. London, UK: Routledge.

Pappas, Takkis S. 2013. "Populist Democracies: Post-Authoritarian Greece and Post-Communist Hungary." Government and Opposition 49(1):1-23. 
Pappas, Christine, Jeanette Mendez, and Rebekah Herrick. 2009. "The Negative Effects of Populism on Gay and Lesbian Rights.” Social Science Quarterly 90(1):150-163.

Reny, Tyler, and Manzano, Sylvia. 2016. "The Negative Effects of Mass Media Stereotypes of Latinos and Immigrants." Media and Minorities 4:195-212.

Reny, Tyler T., Loren Collingwood, and Ali A. Valenzuela. 2019. "Vote Switching in the 2016 Election: How Racial and Immigration Attitudes, Not Economics, Explain Shifts in White Voting." Public Opinion Quarterly 83(1):91-113.

Rico, Guillem, Marc Guinjoan, and Eva Anduiza. 2017. "The Emotional Underpinnings of Populism: How Anger and Fear Affect Populist Attitudes." Swiss Political Science Review 23(4):444-61.

Rooduijn, Matthijs, and Tjitske Akkerman. 2015. "Flank Attacks: Populism and Left-Right Radicalism in Western Europe.” Party Politics 23(3):193-204.

Rooduijn, Matthijs and Teun Pauwels. 2011. "Measuring Populism: Comparing Two Methods of Content Analysis." West European Politics 34(6):1272-1283.

Rydgren, Jens. 2008. "Immigration Sceptics, Xenophobes or Racists? Radical Right-Wing Voting in Six West European Countries." European Journal of Political Research 47(6):737-65.

Samson, Frank L. 2013. "Multiple Group Threat and Malleable White Attitudes towards Academic Merit.” Du Bois Review: Social Science Research on Race 10(1):233-60.

Santa Ana, Otto. 2002. Brown Tide Rising: Metaphors of Latinos in Contemporary American Public Discourse. Austin, TX: University of Texas Press.

Schemer, Christian. 2012. "The Influence of News Media on Stereotypic Attitudes toward Immigrants in a Political Campaign." Journal of Communication 62(5):739-57.

Schmuck, Desiree, Jörg Matthes. 2015. "How Anti-Immigrant Right-Wing Populist Advertisements Affect Young Voters: Symbolic Threats, Economic Threats and the Moderating Role of Education." Journal of Ethnic and Migration Studies 41(10):1577-99.

Schulz, Anne, Philipp Müller, Christian Schemer, Dominique S. Wirz, Martin Wettstein, and Wener Wirth. 2017. "Measuring Populist Attitudes on Three Dimensions." International Journal of Public Opinion Research 30(2):316-26.

Smith, Rogers. 1997. Civic Ideals: Conflicting Visions of American Citizenship in U.S. History. New Haven, CT: Yale University Press.

Spierings, Niels, and Andrej Zaslove. 2017. "Gender, Populist Attitudes, and Voting: Explaining the Gender Gap in Voting for Populist Radical Right and Populist Radical Left Parties." West European Politics 40(4):821-47

Spruyt, Bram, Gil Keppens, and Filip Van Droogenbroeck. 2016. "Who Supports Populism and What Attracts People to It?" Political Research Quarterly 69(2):335-46.

Vahudova, Milada A. 2020. "Ethnopopulism and Democratic Backsliding in Central Europe." East European Politics 36(3):318-40. 
Valentino, Nicholas A., Vincent L. Hutchings, and Ismail K. White. 2002. "Cues That Matter: How Political Ads Prime Racial Attitudes during Campaigns." American Political Science Review 96(1):75-90.

Van Hauwaert, Steven M., and Sitjn Van Kessel. 2018. Beyond Protest and Discontent: A CrossNational Analysis of the Effect of Populist Attitudes and Issue Positions on Populist Party Support." European Journal of Political Research 57(1): 68-92.

Wetts Rachel, and Robb Willer. 2019 "Who Is Called by the Dog Whistle? Experimental Evidence That Racial Resentment and Political Ideology Condition Responses to Racially Encoded Messages." Socius 5:1-20.

White, Ismail K. 2007. “When Race Matters and When It Doesn't: Racial Group Differences in Response to Racial Cues." American Political Science Review 101(2):339-54.

Willer, Robb, Matthew Feinberg, and Rachel Wetts. 2016. "Threats to Racial Status Promote Tea Party Support among White Americans.” Social Science Research Network. https://papers.ssrn.com/sol3/papers.cfm?abstract id=2770186.

Wimmer, Anreas. 2008. "The Making and Unmaking of Ethnic Boundaries: A Multilevel Process Theory." American Journal of Sociology 113(4):970-1022.

Zaslove, Andrej. 2004. "Closing the Door? The Ideology and Impact of Radical Right Populism on Immigration Policy in Austria and Italy." Journal of Political Ideologies 9(1):99-118. 


\section{Appendix A. Use of Economic Nationalism in Presidential Candidates' Speeches, 2004-2016}

Study 2 is designed as an indirect test of the bundling hypothesis, that is, the expectation that the activation of Republicans' ethno-nationalist attitudes by exposure to a populist vignette in Study 1 is a result of the bundling of nationalism and populism in the political discourse of Republican political candidates (outside of the experimental setting). We argue that comparable crossdomain effects between economic populism and anti-China chauvinism should be absent among conservative Democrats - even though these respondents are susceptible to the effects of economic nationalism on anti-China chauvinism - because populism and economic nationalism have not been bundled in Democratic political discourse.

We base the latter assumption on two sources of empirical evidence. First, recent scholarship has shown that Democratic presidential nominees have frequently relied on populist claims-making during the past five presidential elections (Dai and Kustov 2022; Bonikowski, Luo, and Stuhler 2022) and that Democratic populism is primarily economic in its content (Bonikowski and Gidron 2016). Second, to confirm that Democratic candidates did not simultaneously employ economic nationalist frames - that is, that economic populism and economic nationalism are not in fact bundled in Democratic political discourse - we examine the content of Democratic presidential candidates' speeches using computational methods.

We constructed the corpus by scraping the speeches of all Republican and Democratic nominees in the 2004-2021 elections, as well the speeches of the main Republican and Democratic primary candidates in the 2021 election, from the UCSB American Presidency Project and the Factba.se archive of Donald Trump's discourse. We then split each speech into five-sentence quasiparagraphs. Based on the assumption that most instances of economic nationalism involve contrasts between the United States and other countries (typically vilifying the latter for their "unfair" trade practices or for "stealing" American jobs), we limit the corpus to a subset of quasiparagraphs that explicitly mention the names of other countries (we use a list of country names from the countrycode R package). This yields 4,130 quasi-paragraphs, ranging from 21 for the 2016 Cruz campaign to 1,370 for the 2016 Trump campaign (the lowest number of speeches for a presidential nominee is 44 for the 2008 McCain campaign). We then analyze the corpus using structural topic models (STM), which allow us to identify combinations of words that frequently cooccur - and thereby constitute latent topics in the data - and to estimate the distribution of these latent topics over the quasi-paragraphs. STM also allows us to test whether specific topics are over-represented among the speeches of specific candidates.

We estimated separate 40-topic models for the speeches of presidential nominees in the 20042016 elections and the speeches of presidential candidates in the 2016 election. Close inspection of the constitutive terms with the highest FREX (frequency-exclusivity) scores revealed four topics in the former sub-corpus and six in the latter that dealt with economic issues (see Tables A1 and A2). We then measured the distribution of these topics by candidate. The results are presented in Figures A1 through A3.

Table A1. Economic nationalism topics (top 15 terms by FREX score), 2004-2016 presidential nominees' speeches. 


\begin{tabular}{cccc}
\hline Trade Competition & Market Manipulation & Plant Offshoring & Trade Treaties \\
\hline treat & product & mexico & trade \\
got & leav & wall & nafta \\
weve & percent & build & sinc \\
better & currenc & ford & lost \\
fair & make & plant & deal \\
good & manipul & pay & manufactur \\
market & compani & car & china \\
way & steel & poland & bill \\
like & devalu & carrier & disast \\
open & china & border & factori \\
compet & appl & wonder & organ \\
price & sell & move & enter \\
anybodi & start & massiv & hillari \\
anywher & tax & applaus & theft \\
rule & applaus & announc & renegoti \\
\hline
\end{tabular}

Table A2. Economic nationalism topics (top 15 terms by FREX score), 2016 presidential candidates' speeches.

\begin{tabular}{cccccc}
\hline $\begin{array}{c}\text { Trade } \\
\text { Treaties }\end{array}$ & $\begin{array}{c}\text { Market } \\
\text { Manipulation }\end{array}$ & $\begin{array}{c}\text { Trade } \\
\text { Competition 1 }\end{array}$ & $\begin{array}{c}\text { Trade } \\
\text { Competition 2 }\end{array}$ & $\begin{array}{c}\text { Labor } \\
\text { Markets }\end{array}$ & $\begin{array}{c}\text { Plant } \\
\text { Offshoring }\end{array}$ \\
\hline lost & china & theyr & wall & worker & plant \\
nafta & currenc & gonna & mexico & laid & move \\
job & busi & your & build & corpor & compani \\
sinc & devalu & sell & deficit & wage & mexico \\
bill & free & make & pay & agreement & ford \\
manufactur & rip & let & trade & trade & car \\
trade & manipul & call & border & buy & job \\
organ & angri & air & billion & hour & announc \\
deal & leader & here & lose & disastr & build \\
sign & bank & stuff & drug & move & factori \\
theft & dump & tax & easi & job & michigan \\
enter & biggest & tell & mexican & union & product \\
factori & massiv & happen & massiv & shut & leav \\
disast & steel & condition & percent & rust & carolina \\
anoth & relationship & stori & smarter & opposit & fire \\
\hline
\end{tabular}

Figure A1 illustrates the marginal proportions of the four topics for the two parties' nominees in the 2004, 2008, 2102, and 2016 elections. The results confirm that economic nationalism is rarely observed among Democratic candidates, with the topics accounting for less than 5 percent of their quasi-paragraphs. In contrast, the 2004 Bush, 2012 Romney, and 2016 Trump campaigns made frequent use of economic nationalism. Figure A2 shows these patterns over time. Consistent with Figure A1, Democratic candidates' use of economic nationalism remained low and stable between 2004 and 2016, whereas Republicans' use of the frame increased monotonically over the same time period. Finally, Figure A3 illustrates the topic proportions for both parties' candidates in the 2016 primary and general elections. Donald Trump is a clear outlier, having relied on economic nationalism in over 30 percent of his quasi-paragraphs that 
Figure A1. Proportion of economic nationalist topics among presidential nominees, 2004-2016.

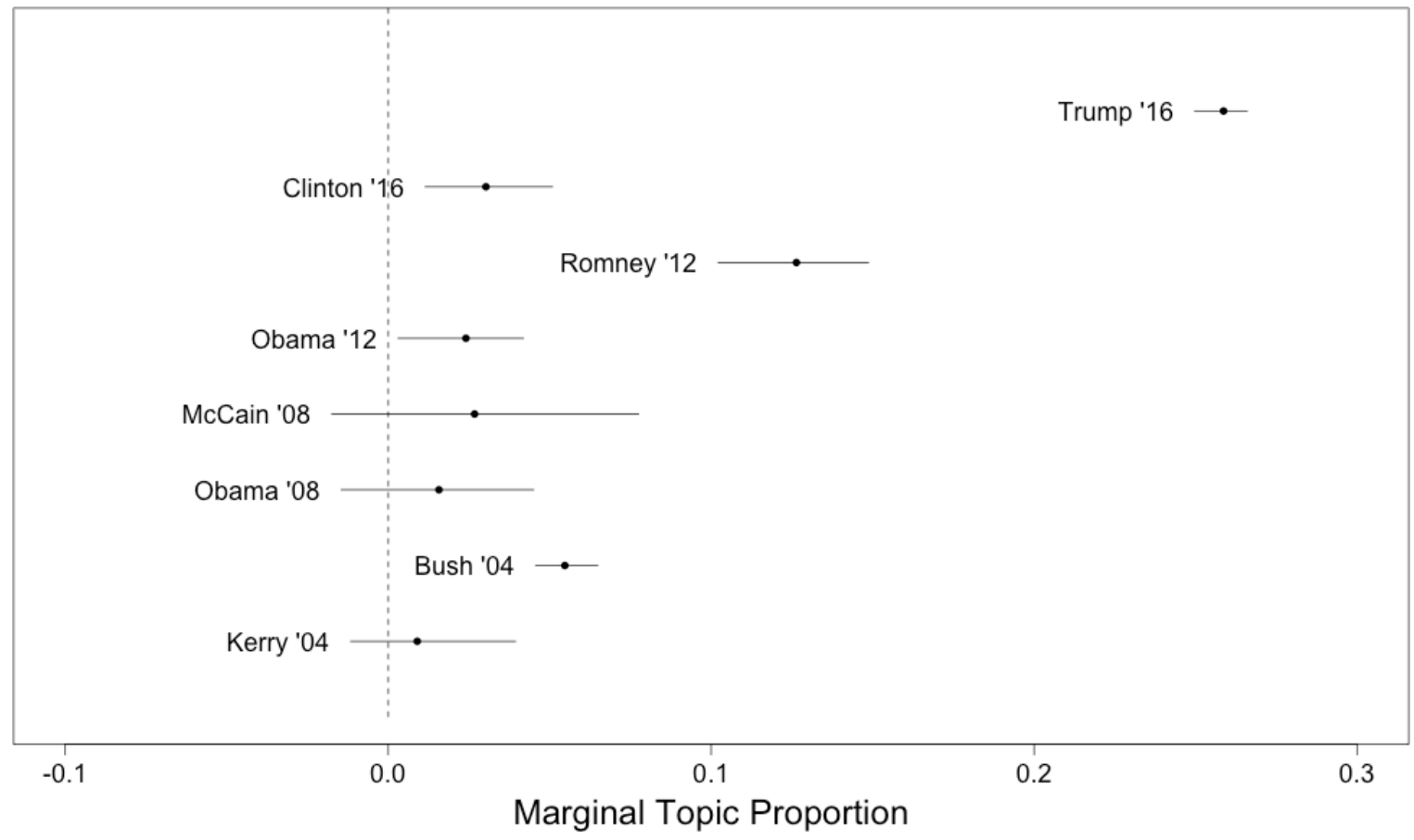

Figure A2. Economic nationalism trends, 2004-2016.

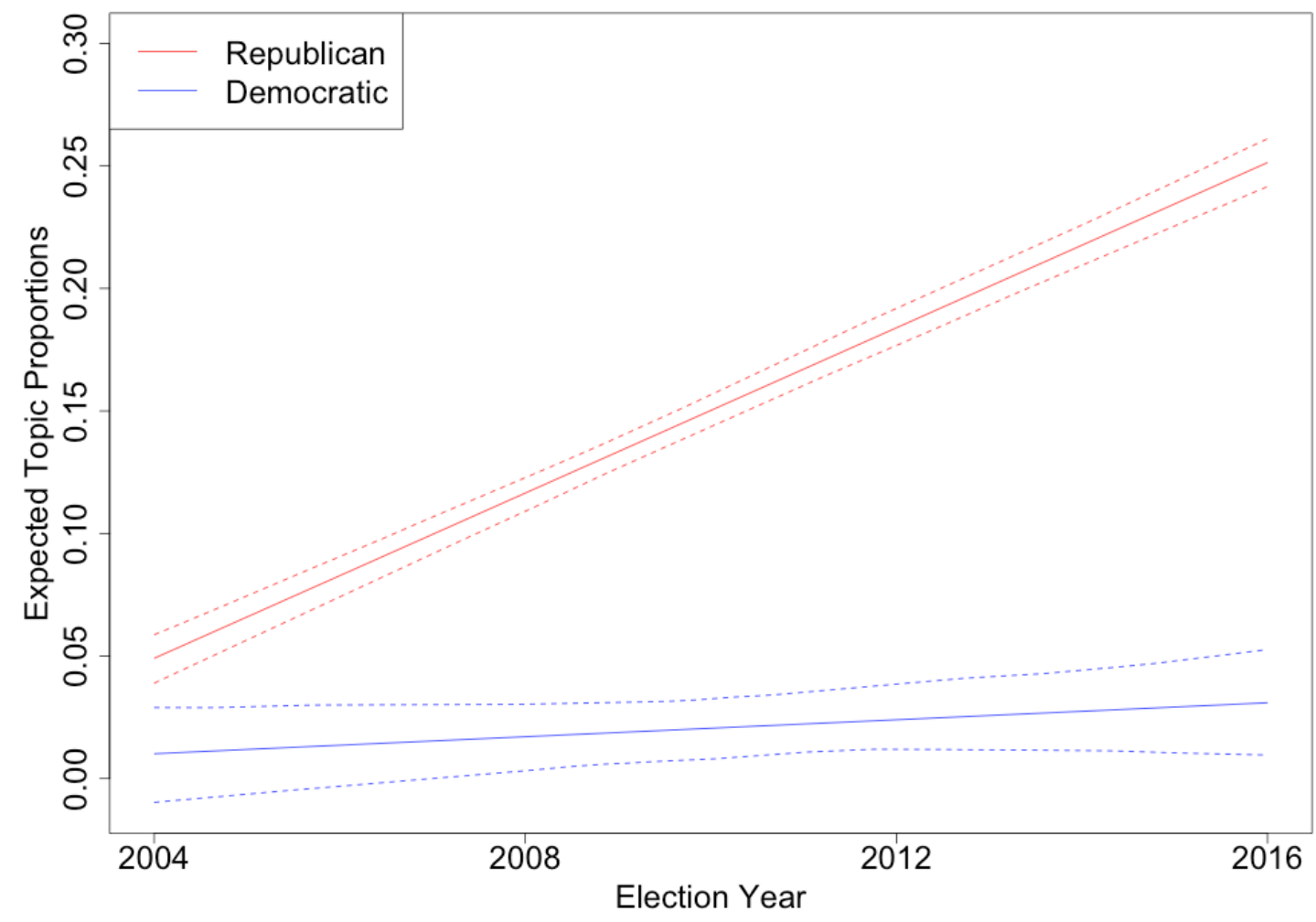


Figure A3. Proportion of economic nationalist topics among presidential primary and generalelection candidates, 2016 election.

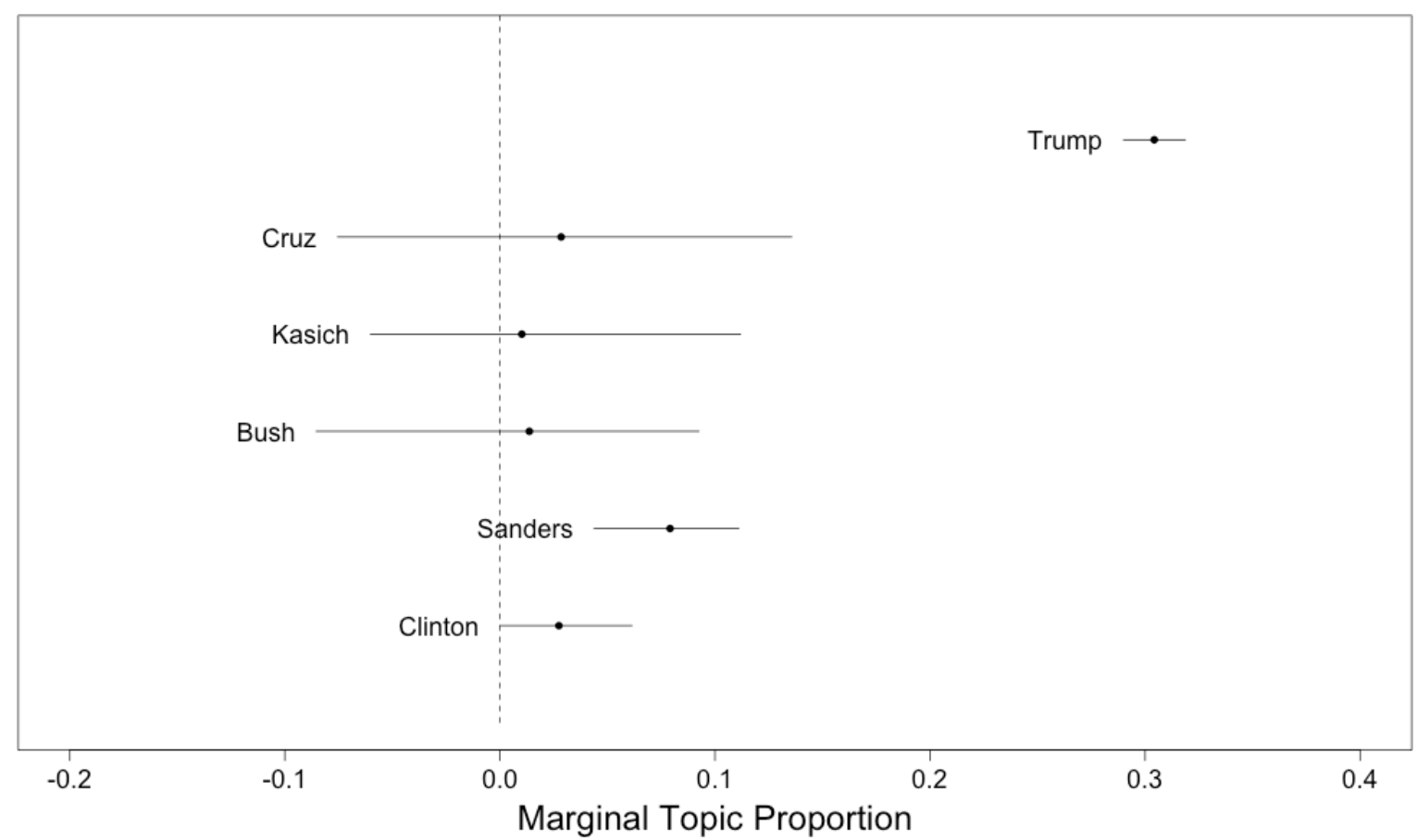

mentioned other countries. The only other candidate to have used this discursive strategy was Bernie Sanders, but he did so in a much smaller proportion of quasi-paragraphs drawn from his speeches.

These results are in line with our intuition: even though they frequently rely on economic populism, Democratic presidential candidates rarely employ economic nationalist arguments in their political discourse, which stands in contrast with their Republican opponents. Even Bernie Sanders, the Democratic candidate most likely to engage in economic nationalism, did so in fewer than 10 percent of quasi-paragraphs from his speeches that mentioned other countries. These findings support our interpretation of the Study 2 design as an indirect test of the bundling hypothesis. 


\section{Appendix B. Descriptive statistics for key variables by condition, Study 1 and 2}

Table A1. Variable proportions/means by condition, Study 1

\begin{tabular}{|c|c|c|c|c|}
\hline Variable & $\begin{array}{c}\text { Control } \\
(\mathrm{N}=1,717)\end{array}$ & $\begin{array}{l}\text { Anti-Gov. } \\
\text { Populism } \\
(\mathrm{N}=1,750)\end{array}$ & $\begin{array}{c}\text { Anti- } \\
\text { Immigrant } \\
(\mathrm{N}=1,744)\end{array}$ & $\begin{array}{c}\text { Total } \\
(\mathrm{N}=5,211)\end{array}$ \\
\hline Gender: Female & $970(56 \%)$ & $947(54 \%)$ & $943(54 \%)$ & $2,860(55 \%)$ \\
\hline Education: High school or less & $501(29 \%)$ & $446(25 \%)$ & $439(25 \%)$ & $1,386(27 \%)$ \\
\hline Education: Associate/college degree & $955(56 \%)$ & $1,031(59 \%)$ & $1,017(58 \%)$ & $3,003(58 \%)$ \\
\hline Education: Graduate degree & $260(15 \%)$ & $273(16 \%)$ & $288(17 \%)$ & $8,21(16 \%)$ \\
\hline One or both parents born in the U.S. & $1,547(90 \%)$ & $1,553(89 \%)$ & $1,554(89 \%)$ & $4,654(89 \%)$ \\
\hline Party: Democrat & $993(59 \%)$ & $1,013(59 \%)$ & $1,026(60 \%)$ & $3,032(59 \%)$ \\
\hline Party: Republican & $559(33 \%)$ & $575(33 \%)$ & $543(32 \%)$ & $1,677(33 \%)$ \\
\hline Party: Independent or other & $132(8 \%)$ & $131(8 \%)$ & $154(9 \%)$ & $417(8 \%)$ \\
\hline Passed manipulation checks & $1,655(96 \%)$ & $1,714(98 \%)$ & $1,684(97 \%)$ & $5,053(97 \%)$ \\
\hline Age (mean) & 38.03 & 37.31 & 37.64 & 37.66 \\
\hline
\end{tabular}

Table A2. Variable proportions/means by condition, Study 2

\begin{tabular}{lcccc}
\hline Variable & $\begin{array}{c}\text { Control } \\
(\mathrm{N}=993)\end{array}$ & $\begin{array}{c}\text { Economic } \\
\text { Populism } \\
(\mathrm{N}=986)\end{array}$ & $\begin{array}{c}\text { Economic } \\
\text { Nationalism } \\
(\mathrm{N}=1,076)\end{array}$ & $\begin{array}{c}\text { Total } \\
(\mathrm{N}=3,055)\end{array}$ \\
\hline Gender: Female & $596(60 \%)$ & $572(58 \%)$ & $637(59 \%)$ & $1,805(59 \%)$ \\
Education: High school or less & $283(28 \%)$ & $250(25 \%)$ & $252(23 \%)$ & $785(26 \%)$ \\
Education: Associate/college degree & $554(56 \%)$ & $572(58 \%)$ & $630(59 \%)$ & $1,756(57 \%)$ \\
Education: Graduate degree & $156(16 \%)$ & $164(17 \%)$ & $193(18 \%)$ & $513(17 \%)$ \\
One or both parents born in the U.S. & $871(88 \%)$ & $876(89 \%)$ & $947(88 \%)$ & $2,694(88 \%)$ \\
Party: Democrat & $993(100 \%)$ & $986(100 \%)$ & $1,076(100 \%)$ & $3,055(100 \%)$ \\
Party: Republican & $0(0 \%)$ & $0(0 \%)$ & $0(0 \%)$ & $0(0 \%)$ \\
Party: Independent or other & $0(0 \%)$ & $0(0 \%)$ & $0(0 \%)$ & $0(0 \%)$ \\
Passed manipulation checks & $961(97 \%)$ & $963(98 \%)$ & $1,059(98 \%)$ & $2,983(98 \%)$ \\
Age (mean) & 37.11 & 36.79 & 36.35 & 36.74 \\
\hline
\end{tabular}




\section{Appendix C. Regression results, Study 1 and 2}

Table C1. Regression results predicting out-group sentiments, Study 1

\begin{tabular}{|c|c|c|c|c|c|c|c|c|c|c|}
\hline & \multicolumn{2}{|c|}{$\begin{array}{l}\text { Minorities } \\
\text { (index) }\end{array}$} & Latinos & $\begin{array}{l}\text { Immigrants } \\
\text { (doc.) }\end{array}$ & $\begin{array}{c}\text { African } \\
\text { Americans }\end{array}$ & $\begin{array}{l}\text { Non- } \\
\text { Religious }\end{array}$ & $\begin{array}{c}\text { Asian } \\
\text { Americans }\end{array}$ & Jews & Muslims & $\begin{array}{l}\text { Immigrants } \\
\text { (undoc.) }\end{array}$ \\
\hline Intercept & $\begin{array}{c}64.80^{* * *} \\
(2.24)\end{array}$ & $\begin{array}{c}67.99^{* * *} \\
(2.25)\end{array}$ & $\begin{array}{c}68.66^{* * *} \\
(2.39)\end{array}$ & $\begin{array}{l}70.44^{* * *} \\
(1.98)\end{array}$ & $\begin{array}{l}68.42^{* * *} \\
(2.38)\end{array}$ & $\begin{array}{c}72.39^{* * *} \\
(2.18)\end{array}$ & $\begin{array}{l}69.59^{* * *} \\
(2.02)\end{array}$ & $\begin{array}{c}67.35^{* * *} \\
(2.13)\end{array}$ & $\begin{array}{l}68.31^{* * *} \\
(2.51)\end{array}$ & $\begin{array}{l}69.39^{* * *} \\
(2.49)\end{array}$ \\
\hline Populism condition & $\begin{array}{c}0.11 \\
(0.82)\end{array}$ & $\begin{array}{c}1.31 \\
(1.06)\end{array}$ & $\begin{array}{c}0.15 \\
(1.11)\end{array}$ & $\begin{array}{l}2.18^{*} \\
(1.01)\end{array}$ & $\begin{array}{c}1.62 \\
(1.14)\end{array}$ & $\begin{array}{c}0.08 \\
(1.11)\end{array}$ & $\begin{array}{c}1.07 \\
(1.05)\end{array}$ & $\begin{array}{c}1.74 \\
(1.09)\end{array}$ & $\begin{array}{c}2.47 \\
(1.28)\end{array}$ & $\begin{array}{l}-0.39 \\
(1.27)\end{array}$ \\
\hline $\begin{array}{l}\text { Anti-immigrant } \\
\text { condition }\end{array}$ & $\begin{array}{l}4.81^{*} \\
(2.22)\end{array}$ & $\begin{array}{l}5.61^{* *} \\
(2.16)\end{array}$ & $\begin{array}{c}7.81^{* * *} \\
(2.31)\end{array}$ & $\begin{array}{l}6.87^{* * *} \\
(1.90)\end{array}$ & $\begin{array}{l}6.99^{* *} \\
(2.30)\end{array}$ & $\begin{array}{l}3.14 \\
(2.10)\end{array}$ & $\begin{array}{l}7.01^{* * *} \\
(1.94)\end{array}$ & $\begin{array}{l}6.67^{* *} \\
(2.05)\end{array}$ & $\begin{array}{l}-0.36 \\
(2.42)\end{array}$ & $\begin{array}{c}-8.82^{* * *} \\
(2.40)\end{array}$ \\
\hline Republican & & $\begin{array}{c}-9.14^{* * *} \\
(1.19)\end{array}$ & $\begin{array}{c}-4.24^{* *} \\
(1.31)\end{array}$ & $\begin{array}{l}-2.89^{*} \\
(1.20)\end{array}$ & $\begin{array}{l}-4.38^{* * *} \\
(1.33)\end{array}$ & $\begin{array}{c}-9.77^{* * *} \\
(1.32)\end{array}$ & $\begin{array}{l}-0.76 \\
(1.23)\end{array}$ & $\begin{array}{c}0.27 \\
(1.29)\end{array}$ & $\begin{array}{c}-18.07^{* * *} \\
(1.52)\end{array}$ & $\begin{array}{c}-31.71^{* * *} \\
(1.51)\end{array}$ \\
\hline $\begin{array}{l}\text { Populism x } \\
\text { Republican }\end{array}$ & & $\begin{array}{l}-4.76^{* *} \\
(1.67)\end{array}$ & $\begin{array}{c}-5.05^{* *} \\
(1.84)\end{array}$ & $\begin{array}{l}-5.42^{* *} \\
(1.68)\end{array}$ & $\begin{array}{l}-4.72^{*} \\
(1.86)\end{array}$ & $\begin{array}{l}-3.50 \\
(1.85)\end{array}$ & $\begin{array}{l}-4.32^{*} \\
(1.73)\end{array}$ & $\begin{array}{l}-2.94 \\
(1.81)\end{array}$ & $\begin{array}{l}-2.77 \\
(2.14)\end{array}$ & $\begin{array}{l}-1.84 \\
(2.12)\end{array}$ \\
\hline $\begin{array}{l}\text { Anti-immigrant } \mathrm{x} \\
\text { Republican }\end{array}$ & & $\begin{array}{l}-3.04 \\
(1.68)\end{array}$ & $\begin{array}{l}-2.65 \\
(1.85)\end{array}$ & $\begin{array}{l}-3.28 \\
(1.70)\end{array}$ & $\begin{array}{l}-2.48 \\
(1.88)\end{array}$ & $\begin{array}{l}-1.91 \\
(1.87)\end{array}$ & $\begin{array}{l}-2.77 \\
(1.74)\end{array}$ & $\begin{array}{l}-4.02^{*} \\
(1.83)\end{array}$ & $\begin{array}{l}-2.96 \\
(2.15)\end{array}$ & $\begin{array}{l}-1.69 \\
(2.14)\end{array}$ \\
\hline $\begin{array}{l}\text { Passed manipulation } \\
\text { checks }\end{array}$ & $\begin{array}{l}-0.33 \\
(0.83)\end{array}$ & $\begin{array}{l}1.85 \\
(1.07)\end{array}$ & $\begin{array}{l}1.31 \\
(1.12)\end{array}$ & $\begin{array}{l}2.57^{*} \\
(1.01)\end{array}$ & $\begin{array}{l}1.50 \\
(1.15)\end{array}$ & $\begin{array}{c}0.55 \\
(1.11)\end{array}$ & $\begin{array}{c}1.51 \\
(1.06)\end{array}$ & $\begin{array}{c}1.22 \\
(1.09)\end{array}$ & $\begin{array}{c}2.09 \\
(1.28)\end{array}$ & $\begin{array}{c}2.04 \\
(1.27)\end{array}$ \\
\hline $\mathrm{N}$ & 3,898 & 3,532 & 4,219 & 4,692 & 4,237 & 4,692 & 4,363 & 4,692 & 4,692 & 4,692 \\
\hline $\mathrm{R}^{2} /$ adjusted $\mathrm{R}^{2}$ & $\begin{array}{c}0.001 / \\
0.000\end{array}$ & $\begin{array}{c}0.081 / \\
0.080\end{array}$ & $\begin{array}{c}0.024 / \\
0.022\end{array}$ & $\begin{array}{c}0.021 / \\
0.019\end{array}$ & $\begin{array}{c}0.022 \text { / } \\
0.021\end{array}$ & $\begin{array}{c}0.049 / \\
0.048\end{array}$ & $\begin{array}{c}0.009 / \\
0.008\end{array}$ & $\begin{array}{c}0.005 / \\
0.004\end{array}$ & $\begin{array}{c}0.101 / \\
0.100\end{array}$ & $\begin{array}{c}0.236 / \\
0.235\end{array}$ \\
\hline
\end{tabular}

Standard errors in parentheses; $* \mathrm{p}<0.05 \quad * * \mathrm{p}<0.01 \quad * * * \mathrm{p}<0.001$ 
Table C2. Regression results predicting sentiments toward China, Study 2, Democrats only

\begin{tabular}{lcc}
\hline & Average effects & $\begin{array}{c}\text { Moderation by } \\
\text { ideology }\end{array}$ \\
\hline Intercept & $54.37^{* * *}$ & $54.95^{* * *}$ \\
Passed manipulation checks & $(3.08)$ & $(3.13)$ \\
& -0.88 & 0.21 \\
Economic populism condition & $(1.13)$ & $(1.46)$ \\
& 0.16 & $-2.93^{*}$ \\
Economic nationalism condition & $(1.15)$ & $(1.42)$ \\
& -4.02 & -3.85 \\
Conservative Democrat & $(3.07)$ & $(3.07)$ \\
& & -1.97 \\
Econ. Populism x Conservative Democrat & & $(1.68)$ \\
& & $5.64 *$ \\
Econ. Nationalism x Conservative Democrat & & $(2.34)$ \\
& & -0.17 \\
$\mathrm{~N}$ & & $(2.38)$ \\
$\mathrm{R}^{2} /$ adjusted $\mathrm{R}^{2}$ & 3,038 & 3,038 \\
\hline
\end{tabular}

Standard errors in parentheses; $* \mathrm{p}<0.05 * * \mathrm{p}<0.01 \quad * * * \mathrm{p}<0.001$ 


\section{Appendix D. Analysis of 2016 ANES data}

To provide additional context for the magnitude of the Study 1 experimental effects, we estimated the association between feeling thermometer scores and anti-immigrant, anti-Latino, and anti-African-American attitudes using the 2016 American National Election Study Pilot Survey $(\mathrm{N}=3,484)$. We regressed four variables - favoring immigration limits, believing that Hispanics are lazy, opposing government help to Blacks, and believing that Blacks are lazy (all dichotomized) — on the Latino / African-American feeling thermometers, along with age, gender, education, and three-category partisan identification. We then calculated the predictive margins of the feeling thermometer variables set at the values observed among Republicans in the control and populism conditions of Study 1 (i.e., 68.3 and 64.6, respectively, for the Latino thermometer and 67.5 and 64.3, respectively, for the African American thermometer), with covariates set to mean age, male, college education, and Republican. Table D1 reports the logistic regression results and predictive margins for the four outcomes.

Table D1. Logistic regression of anti-minority attitudes on feeling thermometers and controls, 2016 ANES Pilot Survey.

\begin{tabular}{|c|c|c|c|c|}
\hline & $\begin{array}{c}\text { Decrease } \\
\text { Immigration }\end{array}$ & $\begin{array}{l}\text { Latinos Are } \\
\text { Lazy }\end{array}$ & $\begin{array}{l}\text { (Don't) Help } \\
\text { Blacks }\end{array}$ & $\begin{array}{c}\text { Blacks Are } \\
\text { Lazy }\end{array}$ \\
\hline Thermometer: Latino & $\begin{array}{l}0.98^{* * *} \\
(0.00)\end{array}$ & $\begin{array}{c}0.97^{* * *} \\
(0.00)\end{array}$ & & \\
\hline Thermometer: Black & & & $\begin{array}{c}1.03^{* * *} \\
(0.00)\end{array}$ & $\begin{array}{c}0.95^{* * *} \\
(0.00)\end{array}$ \\
\hline Age & $\begin{array}{c}1.01^{* * *} \\
(0.00)\end{array}$ & $\begin{array}{c}1.00 \\
(0.00)\end{array}$ & $\begin{array}{c}0.99^{* * *} \\
(0.00)\end{array}$ & $\begin{array}{l}1.00 \\
(0.00)\end{array}$ \\
\hline Male & $\begin{array}{l}0.79^{* *} \\
(0.06)\end{array}$ & $\begin{array}{c}0.89 \\
(0.12)\end{array}$ & $\begin{array}{c}0.92 \\
(0.10)\end{array}$ & $\begin{array}{c}1.07 \\
(0.10)\end{array}$ \\
\hline Party: Independent & $\begin{array}{c}1.87^{* * *} \\
(0.22)\end{array}$ & $\begin{array}{c}1.30 \\
(0.26)\end{array}$ & $\begin{array}{c}0.25^{* * *} \\
(0.04)\end{array}$ & $\begin{array}{l}1.37^{*} \\
(0.20)\end{array}$ \\
\hline Party: Republican & $\begin{array}{c}4.09^{* * *} \\
(0.34)\end{array}$ & $\begin{array}{c}1.16 \\
(0.17)\end{array}$ & $\begin{array}{c}0.08^{* * *} \\
(0.01)\end{array}$ & $\begin{array}{c}2.28^{* * *} \\
(0.24)\end{array}$ \\
\hline Education: $<$ High School & $\begin{array}{c}2.17^{* * *} \\
(0.36)\end{array}$ & $\begin{array}{l}2.02^{* *} \\
(0.48)\end{array}$ & $\begin{array}{c}0.71 \\
(0.17)\end{array}$ & $\begin{array}{c}1.38 \\
(0.27)\end{array}$ \\
\hline Education: High School & $\begin{array}{c}2.11^{* * *} \\
(0.17)\end{array}$ & $\begin{array}{c}1.02 \\
(0.15)\end{array}$ & $\begin{array}{c}0.66^{* * *} \\
(0.07)\end{array}$ & $\begin{array}{c}0.99 \\
(0.10)\end{array}$ \\
\hline Intercept & $\begin{array}{l}0.67^{*} \\
(0.12)\end{array}$ & $\begin{array}{c}0.67 \\
(0.20)\end{array}$ & $\begin{array}{l}0.45^{* *} \\
(0.12)\end{array}$ & $\begin{array}{c}12.24^{* * *} \\
(3.05)\end{array}$ \\
\hline $\mathrm{N}$ & 3,484 & 2,639 & 2,395 & 2,241 \\
\hline $\mathrm{R}^{2}$ Tjur & 0.175 & 0.073 & 0.361 & 0.227 \\
\hline $\operatorname{Pr}($ agree $\mid$ Hisp. therm. $=68.3$ ) & 0.47 & 0.084 & & \\
\hline $\operatorname{Pr}($ agree $\mid$ Hisp. therm. $=64.6$ ) & 0.49 & 0.094 & & \\
\hline $\operatorname{Pr}($ agree $\mid$ Black therm. $=67.5)$ & & & 0.131 & 0.552 \\
\hline $\operatorname{Pr}($ agree $\mid$ Black therm. $=64.3)$ & & & 0.121 & 0.588 \\
\hline
\end{tabular}

Standard errors in parentheses; $* * * \mathrm{p}<0.01, * * \mathrm{p}<0.05, * \mathrm{p}<0.1$ 
Appendix E. Relationship between ideology and China feeling thermometer values, Study 2

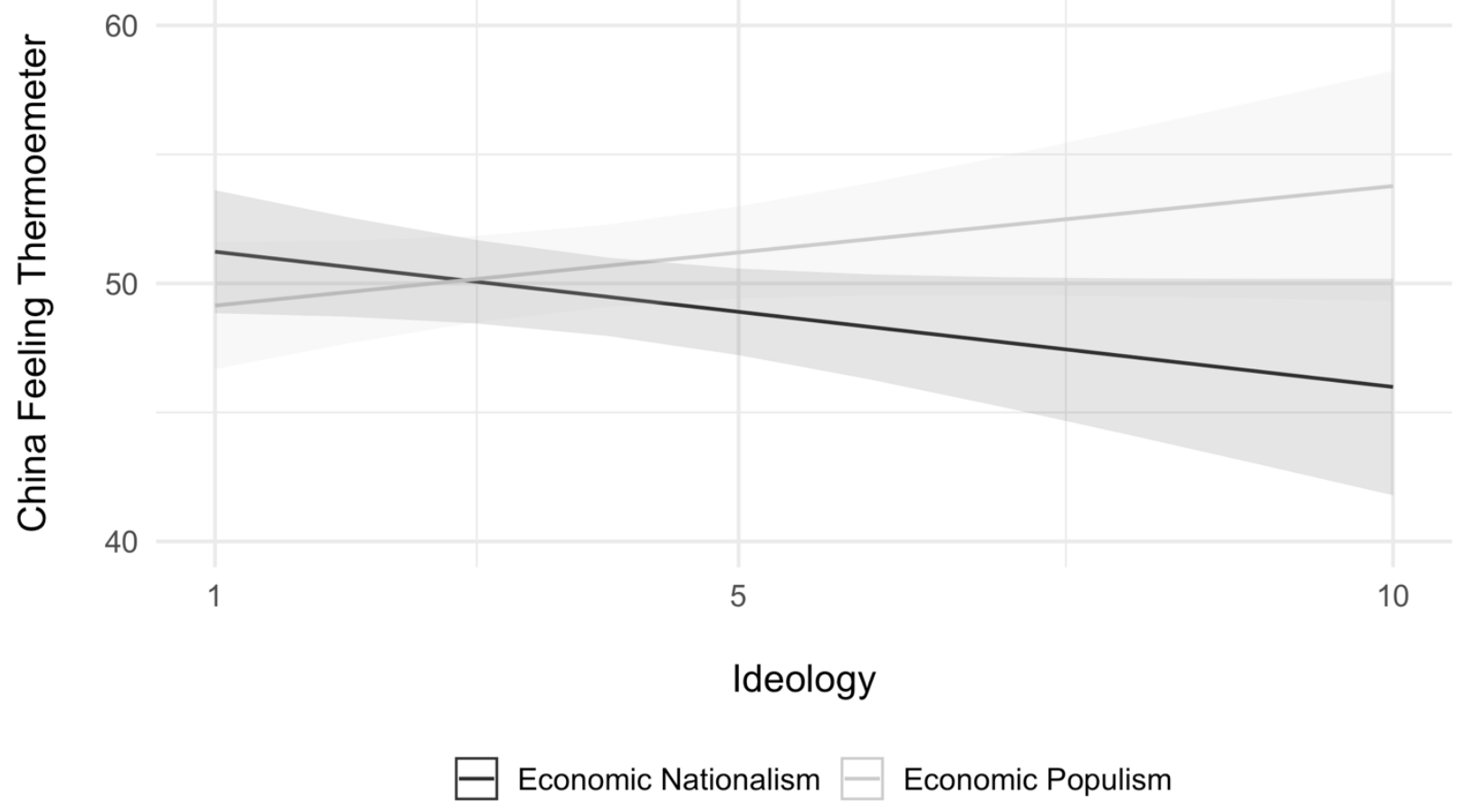




\section{Online Appendix A. Departures from preregistration.}

In our paper, we departed in several ways from the study preregistration (which can be accessed here: https://bit.ly/3IfEQI8). We summarize and justify these changes below.

\section{Hypotheses}

1. In the preregistration, we hypothesized that conservative ideology should be a significant moderator of the cross-domain effects of exposure to populist discourse on ethno-nationalist attitudes. As we developed the study, we initially set this hypothesis aside because it seemed redundant with other moderation models. Upon a helpful suggestion of a reviewer, however, we came to realize that this moderator could be helpful in further bolstering the evidence for the bundling mechanism we posited in the paper-but it would in fact be the absence of a significant effect that we should have expected if our theory was correct. This led us to alter the hypothesis in line with the reviewer's suggestion.

2. Two other preregistered hypotheses sought to explore the moderation of the cross-domain effects by negative immigration attitudes and the mediating role of anger in the relationship between populist message exposure and out-group antipathies. We excluded these hypotheses from the paper in the interest of brevity and simplicity. Both yielded null results, but their implications for our main conclusions are negligible. The moderation hypothesis was largely redundant with the conservative ideology hypothesis in Study 1, so the lack of significant results only further bolsters the likely role of the bundling mechanism in Study 1. The mediation analysis was orthogonal to the main arguments of the paper, so its inclusion would be distracting.

3. In Study 2, limited to Democrats, we had initially anticipated using pre-treatment trade attitudes as the moderator of the cross-domain effects of economic populism exposure on economic nationalism, but we instead chose to focus on conservative ideology as the moderator of choice. This is so, because conservatism turned out to be more closely correlated with both economic populist and economic nationalist attitudes, offering a more appropriate test of the bundling mechanism in Study 2.

\section{Measures}

1. We had initially anticipated operationalizing the minority group feeling thermometers either in their raw form (both individual and in an additive index) or as net scores generated by subtracting each minority thermometer value from the white thermometer value. We selected the former strategy due to its simplicity: it is not obvious how one would deal with a net score in a sample that includes not only whites, but also minority-group respondents who do not identify as white. Although we could have limited the sample to whites only, this was not how we preregistered the study and doing so would have involved the strong (and erroneous, as empirically demonstrated by Bonikowski and DiMaggio [2016]) assumption that ethnonationalism can only be experienced and expressed by white Americans. Furthermore, it is not obvious that heightened ethno-nationalist sentiments must necessarily involve greater identification with whiteness, even among white respondents (though the opposite relationship does appear to hold [Jardina 2019]). Indeed, exposure to the two treatment conditions in Study 1 appears to modestly lower the feeling thermometer scores toward 
whites in the white sample as well, even as it leads to even greater decreases in sentiments toward ethnoracial minorities.

2. In the preregistration, we had described the construction of a six-item racial resentment scale as a possible dependent variable. Given that this scale was not part of any of our hypotheses, we chose to omit it from the study in the interest of brevity and simplicity.

\section{Analyses}

1. The preregistration call for respondents who fail basic attention checks and who fail to complete the survey to be excluded from the analysis. Although we followed the plan in the case of incomplete responses, we chose to retain respondents who failed attention checks. The practice of excluding respondents based on attention check filters has been increasingly discouraged in the experimental methods literature. As a compromise, we control for attention check status in all of our models.

2. In Study 2, we initially intended to swap the conventional null and alternative hypotheses in order to test for the equivalence of means across conditions (within a preset threshold) rather than for the absence of significant differences in means-following the strategy set out by Tryon and Lewis (2008). Although the initial draft of the paper followed this approach, the relative novelty of the method in sociology required a lengthy description. To shorten the paper, we chose to set aside this approach and instead rely on conventional hypothesis testing, with the equivalence of means as the null hypothesis (that in the case of Study 2 cannot be rejected). Both approaches applied to the data in Study 2 lead to the same substantive conclusions.

3. The preregistration called for the use one-tailed significance tests. Given that most of our hypotheses are directional this is not an unreasonable approach. A number of social science journals, however, have discouraged the use of one-tailed tests in recent years. Following best practices, we chose to use a $p=0.05$ threshold of significance for one-tailed tests. This makes our results more conservative than initially planned.

\section{References}

Bonikowski, Bart, and Paul DiMaggio. 2016. "Varieties of American Popular Nationalism." American Sociological Review 81(5):949-80.

Jardina, Ashley. 2019. White Identity Politics. New York: Cambridge University Press, 2019.

Tryon, Warren W., and Charles Lewis. 2008. "An Inferential Confidence Interval Method of Establishing Statistical Equivalence that Corrects Tryon's (2001) Reduction Factor." Psychological Methods 13(3):272-77. 